\title{
Helicobacter pylori Virulence Factors Exploiting Gastric Colonization and its Pathogenicity
}

\author{
Shamshul Ansari ${ }^{1}$ (D) and Yoshio Yamaoka $2,3,4,5, *$ (D) \\ 1 Department of Microbiology, Chitwan Medical College and Teaching Hospital, Bharatpur 44200, Chitwan, \\ Nepal; shamshulansari483@yahoo.com \\ 2 Department of Environmental and Preventive Medicine, Oita University Faculty of Medicine, Idaigaoka, \\ Hasama-machi, Yufu, Oita 879-5593, Japan \\ 3 Global Oita Medical Advanced Research Center for Health, Idaigaoka, Hasama-machi, Yufu, \\ Oita 879-5593, Japan \\ 4 Department of Medicine, Gastroenterology and Hepatology Section, Baylor College of Medicine, \\ 2002 Holcombe Blvd., Houston, TX 77030, USA \\ 5 Borneo Medical and Health Research Centre, Universiti Malaysia Sabah, Kota Kinabaru, \\ Sabah 88400, Malaysia \\ * Correspondence: yyamaoka@oita-u.ac.jp
}

Received: 23 October 2019; Accepted: 16 November 2019; Published: 19 November 2019

\begin{abstract}
Helicobacter pylori colonizes the gastric epithelial cells of at least half of the world's population, and it is the strongest risk factor for developing gastric complications like chronic gastritis, ulcer diseases, and gastric cancer. To successfully colonize and establish a persistent infection, the bacteria must overcome harsh gastric conditions. H. pylori has a well-developed mechanism by which it can survive in a very acidic niche. Despite bacterial factors, gastric environmental factors and host genetic constituents together play a co-operative role for gastric pathogenicity. The virulence factors include bacterial colonization factors BabA, SabA, OipA, and HopQ, and the virulence factors necessary for gastric pathogenicity include the effector proteins like CagA, VacA, HtrA, and the outer membrane vesicles. Bacterial factors are considered more important. Here, we summarize the recent information to better understand several bacterial virulence factors and their role in the pathogenic mechanism.
\end{abstract}

Keywords: Helicobacter pylori; gastritis; peptic ulcer; gastric cancer; CagA; cagPAI

Key Contribution: The H. pylori virulence factors have been defined as the key players in the development of gastric complications, and they are associated with peptic ulcer diseases and gastric cancer.

\section{Background}

Helicobacter pylori, one of the most common bacteria to colonize the gastric epithelium of about half of the world's population, has been estimated to accompany humans for at least 100,000 years [1]. Based on epidemiological data, the bacterium has been categorized as a class-I carcinogen, because it is the strongest known risk factor for severe gastric complication development [2]. Geographic variation was found to influence infection prevalence between countries, and socio-economic status, urbanization level and poor sanitation during childhood has been linked to infection prevalence variation between countries [3]. A recent meta-analysis found that the estimated overall global prevalence was $44.3 \%$, with the prevalence as high as $89.7 \%$ in Nigeria and as low as $8.9 \%$ in Yemen [4].

Although the exact route of bacterial transmission is unknown, documented evidence supports oral-oral or fecal-oral transmission from person to person between family members, and it shows a greater chance of acquiring the infection in the early years of life $[5,6]$. After its transition to the 
gastric lumen, H. pylori colonizes specific sites like the antrum and corpus. H. pylori has well-developed adaptation mechanisms to survive in the harsh gastric acid conditions and to establish a permanent infection (reviewed by Ansari and Yamaoka [7]).

Once the permanent infection is established in the stomach, several gastro-duodenal complications like chronic gastritis, peptic ulcer diseases, gastric cancer, and gastric mucosa-associated lymphoid tissue (MALT) lymphoma may develop [8]. However, the frequency of patients developing severe complications is very low; it has been estimated that less than 1, 10-300, and 100-1000 patients develop MALT lymphoma, gastric cancer, and peptic ulcer diseases, respectively, among every 10,000 patients infected with $H$. pylori [9]. It has been found that approximately $70 \%$ of all gastric ulcers and up to $80 \%$ of all duodenal ulcers are caused by $H$. pylori infection, which is a significant factor causing non-iatrogenic peptic ulcer diseases. The risk of peptic ulcer development increases with previous history of $H$. pylori infection even after its successful eradication compared with non-infected individuals [9]. However, investigations indicate that the recurrence of peptic ulcer diseases decreases with the successful eradication of $H$. pylori infection compared to non-cured patients [10]. The results of a study on the relationship between ulcer disease recurrences and $H$. pylori eradication status found that the recurrence rate of gastric ulcers and peptic ulcers were $4 \%$ and $6 \%$, respectively, in successfully cured patients compared to $59 \%$ and $67 \%$, respectively, in non-cured patients [10]. However, the development of gastric complications like peptic ulcer diseases and gastric cancer is a long-term process that may take several decades, and it is a multifactorial process influenced by gastric environmental, host genetic, and bacterial virulence factors [11].

\section{Virulence Factors Associated with Escape to High Acidic Environment}

After transit to the gastric lumen, the H. pylori encounters extremely harsh conditions of $\mathrm{pH}$ around 2.0. However, H. pylori possesses several factors like urease, bacterial shape and flagella mediating motility to interact with the harsh gastric environment (Table 1). The acidic conditions help the bacteria to express some genetic determinants that neutralize the acidic environment (reviewed by Ansari and Yamaoka [7]).

\subsection{Urease}

A large amount of intracellular urease is produced by H. pylori, constituting around $10 \%$ of the total bacterial protein production. In addition to intracellular urease, $H$. pylori also contains extracellular urease on the bacterial surface due to the lysis of some bacteria in the stomach $[12,13]$.

Urease-catalyzed urea hydrolysis (endogenous and exogenous) results in ammonia $\left(\mathrm{NH}_{3}\right)$ and carbamate production, which is spontaneously decomposed to yield another ammonia $\left(\mathrm{NH}_{3}\right)$ and carbonic acid $\left(\mathrm{H}_{2} \mathrm{CO}_{3}\right)$. The carbonic acid is broken down to $\mathrm{CO}_{2}$ and water $\left(\mathrm{H}_{2} \mathrm{O}\right)$ molecules. Ammonia in its protonated form $\left(\mathrm{NH}_{4}+\right)$ neutralizes stomach acidity and plays an important role in providing a favorable nearly neutral micro-environment around $\mathrm{H}$. pylori [14]. $\mathrm{CO}_{2}$ is converted to bicarbonate $\left(\mathrm{HCO}_{3}{ }^{-}\right)$and $\mathrm{H}^{+}$in the periplasmic space by periplasmic $\alpha$-carbonic anhydrase, maintaining the periplasmic $\mathrm{pH}$ close to 6.1 via an acid acclimation mechanism. In this way, $\mathrm{NH}_{3}$ and $\mathrm{CO}_{2}$ production provides the necessary environment for $H$. pylori's gastric survival $[15,16]$. However, continuous urease expression is required by bacteria for successful colonization even after its survival adaptation in the stomach [17].

In addition to its role in acid neutralization, several in vitro studies uncovered urease's role and its catalytic products in pathogenicity establishment. Ammonia production disrupts the tight cell junctions, breaches the cellular integrity, and damages the gastric epithelium $[18,19] . \mathrm{CO}_{2}$ protects the bacterium from the bactericidal activity of metabolic products like nitric oxide and intracellular killing by phagocytes [20]. Urease was recently reported to possibly contribute to tumor growth and metastatic dissemination by inducing angiogenesis, or new blood vessel formation from pre-existing vasculature, and playing a key role in gastric cancer progression [21]. Chronic H. pylori infection has been found to induce hypoxia-induced factor (HIF), which contributes to the development and progression of several 
cancers. A recent study showed that the $H$. pylori urease activated the PI3K-AKT-mTOR pathway in gastric cells. The activation of this pathway increases HIF- $\alpha$ expression [22]. Moreover, H. pylori urease was found to drive the differentiation of endothelial cells by producing reactive oxygen species and activating the lipoxygenase pathway via pro-inflammatory properties, contributing to $H$. pylori infection progression to gastric carcinogenesis [23]. Furthermore, H. pylori urease was shown to bind to major histocompatibility complex (MHC) class II molecules and induce cell apoptosis [24].

\subsection{Bacterial Shape}

A study of the bacterial shape's role in movement showed that a mutation in the cell shape determinants causing the bacteria to adopt a straight rod morphology reduced the speed of bacterial movement by $7-21 \%$ [25]. Moreover, the results of another study using a mouse infection model showed that the mutant curved $H$. pylori were outcompeted by wild type helical $H$. pylori [26]. These studies suggest that the helical shape is important for the bacterium to penetrate into and move within the viscous mucous layer and for H. pylori's efficient colonization.

The characteristic helical shape of bacteria which provides the bacterial motility also helps to cope with the harsh acidic conditions and adapt to different gastric environments [27]. After transiting to the stomach, the bacteria move from acidic conditions to the mucus layer, which provides a protective layer, before finally moving to the gastric epithelium to establish colonization and infection [25]. The helical bacterial shape facilitates the rapid corkscrew-like bacterial movement within the less acidic mucus layer, allowing the bacterium to escape the extremely low gastric $\mathrm{pH}$ [28]. Moreover, another study highlights the importance of the bacterial helical shape and motility for penetrating the mucus layer and colonizing the gastric epithelium [29].

\subsection{Flagella Mediating Motility}

The flagellum is the locomotory organ that enables the bacterium to move in the ecological niche. H. pylori normally possesses two to six sheathed flagella about $3 \mu \mathrm{m}$ long at one pole [30]. Despite providing harsh conditions, the acid exposure in the gastric niche also activates some proteins that help to escape from the danger. It has been shown that acid exposure activates flagellin, the flagellar proteins leading to enhanced motility. In a study by Merrell et al., the larger percentage of acid-exposed bacteria displayed significantly higher speeds compared to non-acid-exposed bacteria [31].

The number of flagella plays a crucial role in the bacterial cell speed; bacteria with more flagella can move faster compared to cells with fewer flagella. One study demonstrated a 19\% increase in bacterial speed in bacteria possessing four flagella in a viscous environment compared to cells with three flagella [25]. The bacterial cells with greater motility may be deposited with higher density on the gastric epithelium, triggering a higher inflammatory response. It has been found that strains with greater motility increase the sialic acid-binding adhesion (SabA)-mediated interaction of H. pylori, providing a synergistic effect for pathological outcome severity in patients [32].

After infection, the toll-like receptor (TLR) 5 recognizes the flagellin composed of D0, D1, D2, and D3 domains. TLR5 recognition is important for the immunological events necessary for the inflammatory process. A recent study by Forstneric et al. demonstrated the role of flagellin in the TLR5 recognition evasion. In the study, the residues within the domain D0 play a crucial role in flagellin's escape from TLR5 recognition [33].

Therefore, urease, bacterial shape, the number of flagella, and motility allow the bacteria to escape the harsh gastric conditions and help establish persistent infections. 
Table 1. Virulence factors necessary for H. pylori mediated pathogenicity.

\begin{tabular}{|c|c|c|c|}
\hline Virulence Factors & Mechanism & Effects & References \\
\hline \multicolumn{4}{|c|}{ Acid escape virulence factors } \\
\hline \multirow{5}{*}{ Urease } & \multirow{3}{*}{ Production of $\mathrm{NH}_{3}$ and $\mathrm{CO}_{2}$} & Neutralizes the gastric acidity & [14-16] \\
\hline & & $\mathrm{NH}_{3}$ damages the gastric epithelium & {$[18,19]$} \\
\hline & & $\mathrm{CO}_{2}$ protects the bacteria from killing by metabolic products & [20] \\
\hline & Angiogenesis & Causes gastric cancer progression & [21] \\
\hline & Activation of PI3K-AKT-mTOR pathway & Enhances the progression of cancers & [22] \\
\hline Bacterial shape & Helical bacterial shape & Enhances the bacterial penetration into the mucous layer protecting the bacteria & [28] \\
\hline Flagella & Flagellin activation & Displays higher motility that protects the bacteria & [31] \\
\hline \multicolumn{4}{|c|}{ Epithelial cells colonizing factors } \\
\hline \multirow{3}{*}{ BabA } & \multirow{3}{*}{ Binds with the epithelial cell receptor Leb } & Mediates bacterial attachment and colonization & [34] \\
\hline & & Enhances CagA translocation & [35] \\
\hline & & Induces double strand breaks in the host cells & {$[36]$} \\
\hline SabA & Binds with sialyl-Lex antigen & Mediates bacterial attachment and colonization & [37] \\
\hline \multirow{3}{*}{ OipA } & \multirow{3}{*}{ Bacterial adherence to the gastric epithelium } & Damages mucosal layer & [38] \\
\hline & & Induces interleukin (IL)-8 expression & [38] \\
\hline & & Causes host cell apoptosis & [39] \\
\hline HopQ & Bacterial adherence to the gastric epithelium & Inhibits immune cell activities & [40] \\
\hline \multicolumn{4}{|c|}{ Epithelial cells pathogenicity factors } \\
\hline cagPAI & Encodes syringe like T4SS & Translocation of CagA and peptidoglycan & [41-44] \\
\hline CagT & Acts as core complex protein in T4SS & Helps in the translocation of CagA & [45] \\
\hline \multirow{2}{*}{ CagY } & \multirow{2}{*}{ Binds with integrin } & Modulates the immune response to promote the bacterial persistence & [46] \\
\hline & & Alters T4SS functions & [47] \\
\hline $\operatorname{Cag} \zeta$ & Unknown & Associates with T4SS function and mediates CagA delivery & [48] \\
\hline \multirow{2}{*}{ CagL } & \multirow{2}{*}{ Acts as core complex protein in T4SS and binds with integrin } & Helps in the translocation of CagA & {$[42,49]$} \\
\hline & & Induces IL-8 expression & [50] \\
\hline
\end{tabular}


Table 1. Cont.

\begin{tabular}{|c|c|c|c|}
\hline Virulence Factors & Mechanism & Effects & References \\
\hline \multirow{4}{*}{ CagA } & \multirow{4}{*}{ Phosphorylation of tyrosine } & Causes cellular proliferation & [51] \\
\hline & & Causes IL-8 expression & [52] \\
\hline & & Causes cell elongation & [53] \\
\hline & & Down regulates the heat shock protein 1 & {$[54,55]$} \\
\hline \multirow{3}{*}{ VacA } & \multirow{3}{*}{ Vacuolization of epithelial cells } & Causes cell vacuolization & [56] \\
\hline & & Causes cell necrosis & [57] \\
\hline & & Causes cellular apoptosis & [58-60] \\
\hline \multirow{3}{*}{ HtrA } & \multirow{3}{*}{ Acts as protease } & Degrades mis-folded proteins & {$[62,63]$} \\
\hline & & Enables delivery of CagA & [64-68] \\
\hline & & Cleaves the tight junction proteins (occluding, claudin-8, and E-cadherin) & [64-71] \\
\hline \multirow{3}{*}{ Outer membrane vesicles } & \multirow{3}{*}{ Clathrin dependent and independent internalization } & Protects pathogen from the toxic effects of reactive oxygen species & [72] \\
\hline & & Impairs cellular functions & [73] \\
\hline & & Induces dendritic cell functions & {$[74,75]$} \\
\hline \multirow{3}{*}{$\gamma$-glutamyl transpeptidase } & \multirow{2}{*}{ Transpeptidation and amino acid synthesis } & Enhances cell apoptosis & [76] \\
\hline & & Arrests cell cycle & [78] \\
\hline & VacA dependent vacuolation of epithelial cells & Epithelial cell destruction & [79] \\
\hline
\end{tabular}




\section{Virulence Factors Associated with Colonization of Epithelial Surfaces}

The outer membrane proteins like blood group antigen-binding adhesin (BabA), SabA, outer inflammatory protein (OipA), H. pylori outer membrane protein (HopQ), and other proteins interact with the receptors found on the host epithelial cells, playing a key role in pathological events of persistent infections (Table 1 ). This interaction also provides several benefits to infecting $H$. pylori strains. The interaction protects the bacterium from washing out during mucus shedding, provides nutrient access to the bacteria, and promotes delivery of bacterial toxins and other effector molecules to the host cells [80-82].

\subsection{Blood Group Antigen-Binding Adhesin}

BabA, an outer membrane adhesin protein, plays a crucial role in bacterial attachment, and it makes a significant contribution to cellular pathogenicity (reviewed by Ansari and Yamaoka [34]). $\mathrm{BabA}$ is an important protein of outer membrane protein (OMP) family with an approximate molecular weight of around 75-80 kDa. Two closely related paralogs, BabB and BabC have been identified [83,84].

H. pylori adheres to the epithelium with the help of BabA as an adhesin on the bacterial surface that interacts with di-fucosylated glycan found on Leb and mono-fucosylated glycan found on H1-antigen, A-antigen, and B-antigen of blood groups $\mathrm{O}, \mathrm{A}$, and B respectively [85-87]. Although the BabA-mediated attachment provides survival adaptation and persistent infections, the functions of $\mathrm{BabB}$ and $\mathrm{BabC}$ are not yet known. The bab gene sequence analysis revealed that there is variability in the middle sequence region and extensive $5^{\prime}$ and $3^{\prime}$ region conservation, particularly between $b a b A$ and $b a b B$. The sequence variability in the middle region of $b a b A$ suggests that this is the location of BabA's receptor-binding function $[84,88]$. The $5^{\prime}$ and $3^{\prime}$ conservation in $b a b$ gene sequences undergo RecA-dependent intragenomic recombination between these homologous genes ( $b a b A, b a b B$ and $b a b C)$, resulting in chimeric genes that may provide benefits to the organisms. The formation of the chimeric gene $b a b B / A$ has been shown to convert non-Leb binding strains to Leb binding strains, or it can abolish babA-dependent adhesion $[89,90]$.

The BabA binding with Leb has been shown to enhance CagA translocation [35] and induce VacA, $\gamma$-glutamyl transpeptidase, and cag-pathogenicity island (cagPAI)-independent double-strand breaks in the host cells [36]. In Western countries, infection with BabA producing strains has been associated with an increased risk for peptic ulcer disease development [91,92]. A recent study highlighted the adherence of strains with a high avidity mediated by BabA-positive pediatric ulcerogenic H. pylori strains [93].

Based on the binding preferences with $\mathrm{ABO}$ blood group antigens, the BabA-positive H. pylori strains can be of two types. The "specialists" prefer to bind only blood group O-specific glycans, while the "generalists" bind blood group $\mathrm{O}$ and blood group A and B-specific glycans [87]. The capability of both specialist and generalist strains to bind with blood group O-specific glycans explains why people with blood group $\mathrm{O}$ are at a high risk for developing duodenal ulcer diseases [87].

\subsection{Sialic Acid-Binding Adhesin}

The OMP SabA binds to gangliosides with fucose substitutions of the N-acetyllactosamine like the dimeric sialyl-Lex antigen. SabA also binds to $\mathrm{N}$-acetyllactosamine-based antigens with terminal $\alpha 3$-linked Neu5Ac, with preferential binding to gangliosides with long $\mathrm{N}$-acetyllactosamine chains [37]. Recently, minor SabA binding gangliosides of the human gastric mucosa, Neu5Aca3-neolactohexaosylceramide and Neu5Aca3-neolactooctaosylceramide, have been identified. They may provide new insight into the molecular basis for the H. pylori chronic infection in human hosts [94].

An enhanced H. pylori colonization density in Leb-negative individuals was reported based on interactions between SabA adhesin and sialylated gastric glycoconjugates [95]. The sabA gene sequence 
can undergo homologous recombination with the homologous gene called $s a b B$, and it can also happen to some extent with hopQ [96].

Several studies reported an association between $s a b A$ expression and an increased risk of chronic gastritis [97-99], intestinal metaplasia, corpus atrophy and even gastric cancer [91,100]. H. pylori-mediated gastric inflammation was shown to alter the gastric mucosa glycosylation with an upregulation of sialyl-Lex antigens and promoting the SabA mediated bacterial attachment to the gastric mucosa [100,101]. Therefore, increased expression of high-affinity SabA binding glycoconjugates in inflamed gastric epithelium supports enhanced adherence of SabA-positive H. pylori, allowing bacterial persistence and gastric pathogenicity establishment [100]. The results of a study conducted by Mahadavi et al. [100] suggest a close relationship between the presence of $s a b A$, the cag-pathogenicity island, and $b a b A$. According to some authors, the combination of SabA with other virulence factors like OipA and BabA gives the best predictive model by which gastric cancer patients can be distinguished from duodenal ulcer patients and normal individuals [102].

\subsection{Outer Inflammatory Protein (OipA)}

OipA is another virulence protein belonging to the H. pylori OMP family, and it is encoded by the oipA gene. The number of CT dinucleotide repeats in the $5^{\prime}$ signal peptide regulates the expression of OipA via a slipped strand mispairing system. The status is designated as "on" when a functional protein is expressed, while expression of a non-functional protein is designated as "off" [103].

The strains expressing a functional OipA are reportedly involved in bacterial adherence to the gastric epithelial cells with mucosal damage [38] and association with host cell apoptosis [39], interleukin (IL)-8 induction [38], duodenal ulcers [104], and gastric cancer development [105,106]. A study report highlighted the oipA gene's association with chronic gastritis development. Strains expressing functional OipA were most frequently isolated from patients with gastric cancer in Western countries [107].

Furthermore, the results of another study reported that patients infected with strains with "on" status oip $A$ possess a higher risk for peptic ulcers and gastric cancer development rather than developing gastritis or functional dyspepsia [108]. A recent study showed that enhanced adherence to epithelial cells and the translocation of CagA in the presence of functional cagPAI is exhibited by the OipA positive strains [104]. The existence of oip $A$ together with $\operatorname{cag} A$ have been suggested to contribute to proliferation and damage to the normal cellular integrity associated with $\beta$-catenin signaling $[109,110]$. Moreover, H. pylori OipA was reported to reduce IL-10 expression and dendritic cell (DC) maturation, contributing to chronic H. pylori infection establishment [111].

\subsection{Helicobacter Pylori Outer Membrane Protein (HopQ)}

HopQ is another H. pylori OMP. Sequence analysis of hopQ from unrelated strains revealed two genotypes classified as type I and type II, which exhibit a high level of genetic diversity [112,113]. H. pylori HopQ contributes to bacterial adherence to epithelial cells interacting with various members of the carcinoembryonic antigen-related cell adhesion molecules (CEACAM) family expressed on the gastric epithelium specifically during gastritis and gastric cancer development [114-116].

In 2005, Cao et al. reported that the H. pylori HopQ type I genotype is associated with increased peptic ulcer development in the US population [117]. Consequently, another study also found a significant association of HopQ type I in gastric ulcers [118] and in gastric cancer development [118,119]. Similarly, studies also found an association between HopQ type II and gastric cancer development [120].

The recent studies highlighted that the interaction between HopQ and CEACAM contributes to gastric colonization [114] and facilitates translocation of the CagA protein into the gastric epithelium to induce pathogenicity $[114,116,121,122]$. A recent study showed that the interaction between HopQ and CEACAM plays a significant role in inhibiting immune cell activities [40]. Moreover, the association of multiple types of H. pylori HopQ (type I and II) has been recently found in the development of B-cell non-Hodgkin lymphoma and HopQ type II with a higher prevalence [123]. 
Therefore, OMP adhesins provide bacterial attachment to host cells and provide an additional role in pathogenicity.

\section{Virulence Factors Associated with Gastric Epithelial Cell Pathogenicity}

\subsection{Cag-Pathogenicity Island (cagPAI)}

H. pylori cagPAI is an approximately $40 \mathrm{~kb}$ long chromosomal region that contains up to 32 genes encoding a multicomponent bacterial type IV secretion system (T4SS) and an effector protein like CagA $[41,124,125]$. The T4SS forms a syringe-like structure that makes contact with the host epithelium and translocates the effector protein CagA and peptidoglycan into the epithelium [41-44]. Electron microscopy revealed T4SS to be a core structure of $41 \mathrm{~nm}$ protruding from the bacterial surface $[49,126]$. At least 17 genes must be expressed to encode the intact T4SS for its essential functions, and 14 genes must be expressed to fully induce IL-8 secretion $[127,128]$. The strains expressing the intact cagPAI are associated with the development of several disorders like chronic gastritis, peptic ulcer diseases, and gastric cancer [129-133]. Moreover, a recent study found that the strains recovered from the ulcer patients contained a significantly higher prevalence of all individual genes and intact cagPAI compared to strains recovered from non-ulcer patients [134].

Some of the cagPAI components are essential for T4SS function or they are important for CagA translocation (Table 1). CagT is essential for translocation of the effector protein CagA into the epithelial cells [45], while others like CagY act as an immune-sensitive molecular regulator that modulates the immune response to promote bacterial persistence and alter T4SS function [46,47]. $\mathrm{Cag} \zeta$ (Cag1), a membrane protein in T4SS, is closely associated with T4SS function, IL-8 expression induction, and CagA delivery to host cells [48]. A recent study uncovered CagQ's role as a membrane protein in T4SS for maintaining CagA expression and CagA-induced apoptotic effects [135].

Another T4SS component, CagL, a pilin-like component encoded by the cagL gene (HP0539), is expressed on the surface of $H$. pylori in a T4SS-dependent manner [124,125] and in collaboration with the human integrin $\beta 1$-containing receptors. In particular, integrin $\alpha 5 \beta 1$ is necessary for the CagA translocation [42,49]. The tripeptide motif arginine-glycine-aspartic acid (RGD) of CagL at residues 76-78 together with the RGD helper sequence, which is a neighboring surface-exposed FEANE (phenylalanine-glutamic acid-alanine-asparagine-glutamic acid) motif was proposed to be essential for the interaction of T4SS with integrin receptors for CagA translocation into host cells [136]. This RGD-dependent binding of CagL to integrins was also shown to trigger intracellular signaling pathways inducing cell pro-inflammatory responses that are CagA translocation-independent $[46,137,138]$. Recent studies found an association of novel CagL variants with chronic gastritis and peptic ulcer disease (PUD) development $[139,140]$. Particular polymorphisms upstream of the RGD motif at amino acid residues 58-62, called the CagL hypervariable motif (CagLHM), are correlated with severe disease progression in a geographically-dependent manner [141,142]. Therefore, cagL deletion was shown to phenocopy complete cagPAI knockout in many respects because of its role as an essential T4SS component $[43,143]$. This behavior was suggested due to the strain being unable to form a functioning T4SS in response to host cell contact without CagL $[49,144]$. Therefore, in addition to CagA, the strain will not be able to translocate the peptidoglycan, DNA, or precursors of lipopolysaccharide into host cells [145-148]. The results of a recent study demonstrated that in addition to playing a crucial role in the translocation of CagA, the H. pylori CagL may also be responsible for H. pylori-induced IL-8 expression via the transforming growth factor (TGF)- $\alpha$ activated epidermal growth factor-receptor (EGF-R) signaling pathway, H. pylori-induced hummingbird phenomena (elongation of the cells), and the bridging of the T4SS to its human target cells [50].

The effector protein CagA is $125-145 \mathrm{kDa}$. It is expressed by the highly virulent $H$. pylori strains possessing cagPAI, and it is absent from less virulent cagPAI negative strains. The synthesized CagA is translocated into the gastric epithelial cells via T4SS. Although H. pylori synthesizes an abundant amount of CagA, a relatively low amount of it is translocated inside the host epithelial 
cells [149]. The translocated intracellular CagA levels are also regulated by autophagy and the ubiquitin-proteasome system, which degrades the translocated CagA [150,151]. The biological activity of CagA is determined by the types and number of well-characterized EPIYA (glutamic acid-proline-isoleucine-tyrosine-alanine) sequences containing EPIYA-motifs at the C-terminal region. H. pylori isolates recovered from Western countries usually possess CagA with EPIYA-A, -B, and $-C$ where the EPIYA-C region can be up to three units long, while the CagA in H. pylori strains recovered from the East Asian countries possess EPIYA-A, -B, and -D sequences. The first two EPIYA sequences, EPIYA-A and EPIYA-B, are carried by almost all CagA, and the third EPIYA sequence (either EPIYA-C in Western strains or EPIYA-D in East Asian strains) is associated with geographic, genotypic, and virulence characteristics [152]. After its translocation into the host epithelial cells, the EPIYA-motifs of CagA undergo tyrosine (Y)-phosphorylation via various cellular kinases like Csk, c-Src, and c-Abl [51,153]. The phosphorylated tyrosine interacts with the Src homology 2 phosphatase (SHP2) or the adapter protein Grb2 [52,154,155] and hinders cell-cell adhesion, cellular proliferation, IL-8 expression, and cellular elongation via the activation of various cell signaling pathways like Ras-ERK MAP kinases (Rap1 $\rightarrow$ B-Raf $\rightarrow$ Erk) and Wnt- $\beta$-signaling [51-53]. A recent study by Li et al. demonstrated that CagA stimulates YAP signaling pathway activation leading to gastric tumorigenesis in AGS cells. This in vitro result was also supported by the finding that $H$. pylori infection could enhance YAP expression activation in concert with E-cadherin suppression in chronic gastritis tissues infected with H. pylori compared to H. pylori negative patients [156].

The CagA with EPIYA-D motif has stronger binding affinity with SHP2 than the EPIYA-C motif [157]. Therefore, the strains containing CagA with EPIYA-A, -B, and -D motifs are considered more virulent than strains containing CagA with EPIYA-A, -B, and -C motifs. In a recent meta-analysis, CagA with a single EPIYA-D motif was significantly associated with a 1.91 fold increased gastric cancer risk in Asia compared with one EPIYA-C motif, and the CagA with two or more EPIYA-C motifs (EPIYA-A, -B, -C, -C or EPIYA-A, -B, -C, -C, -C) was associated with a significantly higher risk for PUDs in Asian countries and gastric cancer (OR (odd ratio) $=3.28$ ) in the US and Europe [158]. In addition to the type of EPIYA-motifs, strains with amino acid polymorphism within the Western-specific EPIYA-B motif like EPIYT-B may influence CagA activity, reducing the ability to induce hummingbird phenomena and IL-8 expression conferring lower risk for gastric cancer and a higher risk for duodenal ulcer development [159]. A recent study demonstrated that secreted H. pylori CagA can induce caudal type homeobox 1 (CDX1) expression, which is a homeobox transcription factor that plays an important role in human intestine development and maintenance [160,161]. CDX1 activation promotes cell proliferation, invasion/migration, intestinalization of gastric epithelial cells, and stem cell-like phenotype induction leading to cancer development and failure of common gastric cancer chemotherapies [160]. Recently, another study discovered CagA-mediated downregulation of heat shock protein 1 (HSP1) expression after H. pylori infection [54]. CagA-dependent acute HSP1 suppression represses the host immune response, so H. pylori may escape from the immune response and enhance infection establishment [55]. Although cagPAI positive H. pylori is considered as the strongest risk factor for the development of the gastroduodenal complications, the precise mechanism behind the development of severe complications is still not completely understood. Recently, a study has pointed out the role of $\mathrm{H}$. pylori cagPAI in the expression of Lrig1 (leucine-rich repeats and Ig-like domains 1) in a CagA and CagE-dependent manner. Lrig1 is a transmembrane protein that acts as an intestinal stem/progenitor cell marker. The study demonstrated a significant increase in Lrig1-positive cells in the premalignant lesions (atrophic gastritis and intestinal metaplasia) in the antrum and corpus compared with that in the normal mucosa and stomach lining, which indicates the possible contribution of these cells to the ability of H. pylori to cause injury and promote carcinogenesis in the stomach [162].

\subsection{Vacuolating Cytotoxin (VacA)}

VacA is an important $H$. pylori pore-forming cytotoxin that plays a crucial role in pathogenicity by interacting with gastric epithelial cells $[163,164]$. The ability of this toxin to induce vacuole formation 
in eukaryotic cells led to it being named VacA. Initially, VacA is formed as a $140 \mathrm{kDa}$ pro-toxin that is secreted through the auto-transporter pathway. The mature $88 \mathrm{kDa}$ secreted toxin undergoes limited proteolysis to yield two fragments: p33 and p55 [165].

The three heterogenic regions of VacA have significant sequence variation. The " $\mathrm{s}$ " region represents the sequence variation in the amino-terminal signal sequence. The " $\mathrm{m}$ " region represents the amino acid variation located in the middle of the p55 domain. The " $\mathrm{i}$ " region was recently identified in a survey conducted in the Iranian population, and it represents the amino acid variation in the intermediate region located between the " $\mathrm{s}$ " and " $\mathrm{m}$ " region in the p33 domain [166-168]. The sequence variation of VacA isolated from the clinical H. pylori isolates indicates the s1a, s1b, s1c, and s2 sub-families of the " $\mathrm{s}$ " region. $\mathrm{m} 1$ and $\mathrm{m} 2$ are sub-families of the " $\mathrm{m}$ " region. $\mathrm{i} 1$, $\mathrm{i} 2$, and $\mathrm{i} 3$ are sub-families of the " $\mathrm{i}$ " region [166,168-170]. The allelic diversity was reviewed in detail by Tran et al. [171].

The studies have revealed that the combination of different sequences in the three regions can determine the capability of vacuolation. Moreover, the genotype possessing the combination $\mathrm{s} 1 / \mathrm{m} 1$ exhibits high vacuolating activity, and the genotype $\mathrm{s} 1 / \mathrm{m} 2$ has intermediate activity. On the other hand, no vacuolating activity was shown by the genotype s2/m2 [166]. This finding indicates that the vacuolating capability of VacA with the s2 genotype is lower than the s1 genotype. The s2 region contains an additional 12 amino acids in the $\mathrm{N}$-terminal sequence causing the predominant hydrophilic nature compared to the strongly hydrophobic s1 region, which most probably causes impairment in the anion-selective channel formation and cell vacuolation [170]. The lower vacuolating activity was also supported by the fact that VacA export with the s2 genotype from the cytoplasmic membrane to the periplasmic space is less efficient compared to s1 genotypes [172]. The strains with the s1 sequence were reported to secrete higher amounts of VacA that may be caused by elevated vacA transcription than s2 type strains [173]. Therefore, these differences could cause the higher activity of vacuolation by strains possessing VacA with the $\mathrm{s} 1 / \mathrm{m} 1$ genotype.

In clinical H. pylori isolates from ulcer patients, a higher prevalence of VacA with s1a, m1, and i1 genotypes have been detected compared to patients with non-ulcer diseases [134]. A meta-analysis conducted in Western populations found that the individuals pose an increased risk for gastric cancer development if they are infected with $H$. pylori harboring vacA with $\mathrm{s} 1 \mathrm{or} \mathrm{m} 1$ regions [174]. On the other hand, in Middle Asia and Middle East Asia, patients infected with vacA i1 type harboring H. pylori are associated with a high risk for gastric cancer development (OR = 10.9-15.0) [175]. The antibody against VacA is associated with an increased risk for gastric cancer development [176]. A recent meta-analysis conducted by Li et al. observed an association of a VacA antibody with peptic ulcer disease and gastric cancer risk, which suggests the role of VacA as a biomarker for the prediction of peptic ulcer disease and gastric cancer risk [177]. Furthermore, a strong antibody response to H. pylori VacA is significantly associated with the risk of extra-gastric diseases such as colorectal cancer development, particularly in African Americans [178].

VacA plays several roles in cellular pathogenicity (Table 1), and it is considered a multifunctional toxin eliciting multiple effects on host cells like vacuolization and cell necrosis [56,57]. Numerous studies have also shown cell apoptosis induction by VagA through the mitochondrial pathway in gastric epithelial cells [58-60]. An additional apoptotic potential was elaborated in a study, which provided novel evidence that VacA triggers the endoplasmic reticulum stress response to activate autophagy and increased cellular death of AGS cells [61]. The studies have found that the 148 amino acid segment localized at the middle region exploits the cell binding specificity of VacA, and strains harboring VacA have the best survival for H. pylori inside the gastric epithelial cells [179-181]. A recent study reported that the VacA promotes bacterial survival independent of CagA accumulation [151]. This survival efficacy was determined in a recent study where the H. pylori VacA can play an important role in a transient receptor potential membrane channel mucolopin 1 (TRPML1) activity that inhibits the lysosomal and autophagic killing of bacterial cells to promote the establishment of an intracellular niche that allows for bacterial survival [182]. 


\subsection{High-Temperature Requirement Protein (HtrA)}

Organisms are continuously exposed to oxidative and heat stress that can kill them. However, organisms tolerate these stresses and degrade intracellular irreversibly misfolded proteins that may be toxic to the organisms [62,63]. The protease HtrA plays an important role in neutralizing the effects of these stress responses in both prokaryotes and eukaryotes like humans [183-186]. When encountering denatured or misfolded proteins, HtrA undergoes oligomerization and conformational changes to switch to proteolytic activity (Table 1). The HtrA protein is generally transported in the periplasmic space, where they form proteolytically active oligomers which exhibit both protein quality control and chaperone functions $[187,188]$. However, the HtrA protein is transported extracellularly in $H$. pylori $[62,189,190]$. H. pylori $\mathrm{HtrA}$ is highly resistant to temperature and $\mathrm{pH}$ variations, which indicates its ability for adaptation and causing colonization and persistent infection even in harsh stomach conditions [191,192].

The extracellularly exported HtrA enables the bacteria to deliver the virulence factor like CagA to the basolateral membrane of host cells despite infection initiation at the apical side [64-68]. The serine protease activity of the $H$. pylori HtrA protein was found to cleave the proteins of tight junctions like occludin, claudin-8, and the E-cadherin molecules on the gastric epithelial cells, which are important adherens junction proteins and tumor suppressors. Moreover, their destruction has been strongly connected with the progression and metastasis of gastric tumors in humans [64-71]. The findings have also suggested that the HtrA-mediated E-cadherin destruction causes the disruption of the epithelial barrier and transmigration of $H$. pylori across the polarized gastric epithelial linings $[65,70,193]$. The results of a recent study found that the htrA gene in $H$. pylori is one of the highly conserved genes to be found in isolates from Europe, Asia, North America, and South America. This conservation suggests that there is little or no effect on the htrA gene region over the course of $H$. pylori and human co-evolution like the H. pylori MLST housekeeping genes [68].

\subsection{Outer Membrane Vesicles}

Outer membrane vesicles (OMVs) are characterized as blebs of 20-300 nm in diameter which are naturally secreted by several Gram-negative bacteria including $H$. pylori during their growth in logarithmic phase [194-196]. Since OMVs are released from the outer membrane of bacteria, they contain several outer membrane specific phospholipids like phosphatidylglycerol (PG), phosphatidylethanolamine (PE), lyso-PE (LPE), phosphatidylcholine (PC), lyso-PC (LPC), cardiolipin, lipopolysaccharides, and several bacterial virulence factors like adhesins, proteases, and toxins [197-201]. After their release, these OMVs are taken up by gastric epithelial cells via clathrin-dependent endocytosis or a clathrin-independent mechanism (lipid raft-mediated mechanism) [202]. Moreover, the H. pylori OMVs have been reported to protect the pathogen from the toxic effect of the reactive oxygen species respiratory burst [72].

OMVs have been detected intracellularly and extracellularly in gastric biopsy specimens $[199,200,203]$. In addition to protecting the pathogen, they have been suggested to promote infection, impair cellular function, and modulate host immune defenses via immunosuppressive cytokine IL-10 production by human peripheral blood mononuclear cells and via apoptosis in Jurkat T cells $[73,204,205]$. Similarly, H. pylori OMVs have been also found to induce dendritic cells by upregulating the expression of co-stimulatory molecules and expression of more heme oxygenase- 1 via the activation of Akt-Nrf2 and mTOR-кB Kinase-NF- $\mathrm{kB}$ pathways [74,75]. Moreover, the studies have detected H. pylori OMVs in the gastric juice of patients with gastric cancer [206,207]. In a recent study conducted by Choi et al., the gastric juice collected from gastric cancer patients showed a significantly higher amount of both $H$. pylori cells and the H. pylori-derived OMVs compared to healthy controls. Furthermore, these H. pylori-derived OMVs also induced inflammation in the mouse model, inducing gastric cancer development [207]. 


\subsection{H. pylori $\gamma$-Glutamyl Transpeptidase}

H. pylori $\gamma$-glutamyl transpeptidase (gGT) is an enzyme that catalyzes the transpeptidation and hydrolysis of the $\gamma$-glutamyl moiety of glutathione and glutathione-conjugated compounds to amino acids [208]. Although gGT is an essential component for $H$. pylori infection in mice, the deletion of gGT has no inhibitory effect on the ability to grow on the culture media [209]. A study using two distinct animal models (mice and piglets) with $H$. pylori infection indicates that in infection with gGT-deficient strains, the colonization is reduced in comparison to the infection with the isogenic wild type strains. The consistent results in these two animal models also suggest that the presence of gGT provides at least some advantage to allow H. pylori to infect epithelial cells [210]. The study suggests that $H$. pylori gGT provides a growth advantage within the gut by salvaging extracellular glutathione to obtain cysteine for subsequent protein synthesis and the activity is greatest at a neutral $\mathrm{pH}[209,210]$. Recently, a similar result of significantly higher colonization with gGT-positive strains was suggested by Wustner et al. [211]. Moreover, a recent study described the novel role of H. pylori gGT in autophagy regulation and bacterial internalization in human gastric cells, which suggests the possible role of gGT in the protection of bacteria to commence a persistent infection [212].

H. pylori gGT induces apoptosis, inhibits gastric cell proliferation, arrests the cell cycle, and generates reactive oxygen species [76-78,213,214] and the significantly higher activity of gGT has been demonstrated in strains isolated from patients with peptic ulcer disease and gastric cancer, which suggests the possible role of gGT in the contribution to severe pathogenicity [214,215]. Furthermore, a recent study revealed the role of gGT in accentuating VacA-dependent vacuolation of epithelial cells [79]. The enhancement of vacuolation by gGT is carried out by the hydrolysis of extracellular glutamine, thereby releasing ammonia which accentuates VacA-dependent vacuolation. This discovery suggests why H. pylori with higher activity of gGT exhibits more severe gastro-duodenal diseases.

\section{Other Virulence Factors Playing a Role in Triggering Pathogenicity}

Despite of the above-mentioned well-characterized virulence factors, several studies have depicted the association of other virulence factors in the severity of gastric complications. A recent study conducted by Capitani et al. described the possible role of the HP1454, a secreted protein and component of OMVs, in the Th1 and Th17-mediated inflammatory response in the chronic H. pylori infection and associated gastric cancer [216]. In addition to cagPAI encoding the T4SS, another putative gene cluster with low $\mathrm{G}+\mathrm{C}$ content of around $35 \%$ encoding the T4SS in H. pylori is located within the integrating conjugative elements (ICE). Recently, we reported the role of the specific variants of $H$. pylori ICE T4SS (ICEhptfs) in pathogenicity. In the study, the cagPAI-mediated acute inflammation in the antrum and body was ICEhptfs-dependent, and this dependency was also attributed to the higher atrophy score in antrum [217]. The expression of cholesterol glycosyl-transferase (CGT) that depletes cholesterol in infected gastric epithelial cells blocks IFN-gamma signaling and protects bacteria from the inflammatory response. This discovery suggests a novel mechanism of $H$. pylori CGT utilization for the promotion of gastric carcinogenesis [218].

\section{Whole Genome Sequencing and Genome Wide Association Studies (GWAS) Approach for Virulence Determination}

In recent years, the whole genome sequencing (WGS)-based approach from cultured bacterial isolates has emerged as one of the most comprehensive tools for surveillance study, drug resistance determination, and evolutionary analysis of infectious diseases [219-224]. This is due to improved sequencing technologies, the user friendly nature, easy availability of reagents, improved accuracy of up to $93 \%$, reasonably lower costs (150EUR per 5 MB genome by Illumina MiSeq), and faster results (nine days versus 21 days) compared to traditional DNA sequencing [221,222,225-227]. In addition to these benefits, the WGS also offers a more comprehensive and accurate tool for genome analysis.

Recently, the WGS has been used to characterize a variety of pathogens to determine the novel or existing virulence factors. In a study, Hurley et al. performed WGS-based characterization of 
100 Listeria monocytogenes strains to determine disease epidemiology, the presence of drug resistance genes, and to determine virulence factors [223]. Similarly, another study was conducted by Edwards et al. to characterize the putative virulence factors in Plesiomonas shigelloides [228]. Furthermore, Aly et al. used a WGS-based study to identify genes associated with biofilm formation, antibiotic resistance, and pathogenicity [224]. The results of these studies clearly suggest that WGS-based approaches are an advancement over traditional Sanger sequencing.

Currently, the WGS tool is mostly being used to determine the presence of antibiotic resistance genes in H. pylori [229-232] because of the absence of the resistance determinants in plasmids, transposons, or integrons [233]. However, this approach has recently gained popularity in virulence determination. In a recent study, Ogawa et al. performed WGS of 43 clinical isolates H. pylori (17 chronic gastritis, eight gastric ulcers, eight duodenal ulcers, and 10 gastric cancers). Full cagL and cagI sequences were analyzed for single nucleotide variation and amino acid changes. The WGS results identified several putative novel variants of CagL and CagI sequences, proving its usefulness in virulence determination [234]. The search for the genetic basis of susceptibility to particular diseases using populations with the specific diseases and matched controls and GWAS has become popular in human genetics [235]. Recently, this novel state of the art methodology was used in H. pylori to search for the novel virulence factors using genomic information from strains isolated from gastric cancer and matched controls like isolates from the duodenal ulcers. Berthenet et al. used GWAS in their recent study to illustrate the association of the presence of the cagPAI genes cag11 (cagV), cag12 (cagU), and cag 20 (cagI) in H. pylori isolated from patients with gastric cancer [236].

\section{H. pylori and Microbiota in Gastric Carcinogenesis}

H. pylori promotes carcinogenesis by influencing the composition of the microbial population (microbiota) in the stomach [237-239]; however, the mechanism is not fully understood. The precise balance of commensal microbiota in the gastrointestinal tract plays a role in the regulation of the host mucosal immune response, efficient killing of potential pathogens, and carcinogenesis [240-244]. Studies have suggested that some of the microbes including Escherichia coli, Lactobacillus spp., Nitrospirae spp., Clostridium spp., Veillonella spp., Haemophilus spp., and Staphylococcus spp. that convert nitrogen compounds to potentially carcinogenic $\mathrm{N}$-nitroso compounds in gastric fluid enhance cancer development [238,245-247], whereas oral commensals such as Streptococcus spp., Prevotella spp., and Neisseria spp. are associated with a lower risk for gastric cancer development [244,248]. In contrast, other oral microbes such as Pasteurella stomatis, Spodoptera exigua, Parvimonas micra, Streptococcus anginosus, and Dialister pneumosintes exhibit a strong co-occurrence in gastric carcinogenesis [243]. In a study, Wang et al. observed an abundant presence of five bacterial genera (Lactobacillus spp., Escherichia coli, Shigella spp., Nitrospirae spp., Burkholderia fungorum, and Lachnospiraceae spp.) in gastric cancer patients, where Nirospirae spp. was observed in all gastric cancer patients but not in chronic gastritis patients [247]. A recent study has described the alteration in the relative abundances of the dominant phyla Bacteroidetes, Firmicutes, and Proteobacteria in the fecal microbiota of subjects with $H$. pylori-positive gastric precancerous lesions, which suggests the possible association of these phyla with the progression of $H$. pylori related gastric lesions [249]. The co-excluding and co-occurring interactions of $H$. pylori with Methylobacillus and Arthrobacter, respectively, in severe gastritis has been observed, whereas co-excluding interactions with members of the phylum Firmicutes (Ruminococcus, Bacillales, and Lactobacillus) and co-occurrence interactions with Prevotella, Moryella, and another helicobacter (H. ganmani) have been reported [243]. Therefore, site-specific gastric microbiota that colonize the tumor microenvironment are an important factor for carcinogenesis and its progression.

\section{Conclusions}

This study depicts the importance of several virulence factors playing a role in the severity of gastric complications. H. pylori infections contribute the highest risk for developing severe gastric diseases. Therefore, the virulence factors characterized in the isolated strains will provide a clue 
for the disease prediction in the populations. Currently, WGS and GWAS-based investigations and their meaningful results for the putative virulence and drug resistance determinants have encouraged researchers to perform more extensive and multidisciplinary efforts for better understanding of virulence factor involvement in the onset and progression of gastric complications.

Author Contributions: Conceptualization, Y.Y.; methodology, Y.Y. and S.A.; literature review, S.A.; original draft writing, S.A.; draft supervision, review and editing, Y.Y.; funding acquisition, Y.Y.

Funding: Ministry of Education, Culture, Sports, Science and Technology: 15H02657. Ministry of Education, Culture, Sports, Science and Technology: 16H06279. Ministry of Education, Culture, Sports, Science and Technology: 16H05191. Ministry of Education, Culture, Sports, Science and Technology: 18KK0266. National Institutes of Health: DK62813

Conflicts of Interest: The authors declare no conflict of interest.

\section{References}

1. Maixner, F.; Krause-Kyora, B.; Turaev, D.; Herbig, A.; Hoopmann, M.R.; Hallows, J.L.; Kusebauch, U.; Vigl, E.E.; Malfertheiner, P.; Megraud, F.; et al. The 5300-year-old Helicobacter pylori genome of the Iceman. Science 2016, 351, 162-165. [CrossRef] [PubMed]

2. Hatakeyama, M. Structure and function of Helicobacter pylori CagA, the first-identified bacterial protein involved in human cancer. Proc. Jpn. Acad. Ser. B Phys. Biol. Sci. 2017, 93, 196-219. [CrossRef] [PubMed]

3. Hooi, J.K.Y.; Lai, W.Y.; Ng, W.K.; Suen, M.M.Y.; Underwood, F.E.; Tanyingoh, D.; Malfertheiner, P.; Graham, D.Y.; Wong, V.W.S.; Wu, J.C.Y.; et al. Global Prevalence of Helicobacter pylori Infection: Systematic Review and Meta-Analysis. Gastroenterology 2017, 153, 420-429. [CrossRef] [PubMed]

4. Zamani, M.; Ebrahimtabar, F.; Zamani, V.; Miller, W.H.; Alizadeh-Navaei, R.; Shokri-Shirvani, J.; Derakhshan, M.H. Systematic review with meta-analysis: The worldwide prevalence of Helicobacter pylori infection. Aliment. Pharmacol. Ther. 2018, 47, 868-876. [CrossRef]

5. Mamishi, S.; Eshaghi, H.; Mahmoudi, S.; Bahador, A.; Hosseinpour Sadeghi, R.; Najafi, M.; Farahmand, F.; Khodadad, A.; Pourakbari, B. Intrafamilial transmission of Helicobacter pylori: Genotyping of faecal samples. Br. J. Biomed. Sci. 2016, 73, 38-43. [CrossRef]

6. Bui, D.; Brown, H.E.; Harris, R.B.; Oren, E. Serologic Evidence for Fecal-Oral Transmission of Helicobacter pylori. Am. J. Trop. Med. Hyg. 2016, 94, 82-88. [CrossRef]

7. Ansari, S.; Yamaoka, Y. Survival of Helicobacter pylori in gastric acidic territory. Helicobacter 2017, 22, e12386. [CrossRef]

8. Jiang, J.; Chen, Y.; Shi, J.; Song, C.; Zhang, J.; Wang, K. Population attributable burden of Helicobacter pylori-related gastric cancer, coronary heart disease, and ischemic stroke in China. Eur. J. Clin. Microbiol. Infect. Dis. 2017, 36, 199-212. [CrossRef]

9. Kuipers, E.J.; Thijs, J.C.; Festen, H.P. The prevalence of Helicobacter pylori in peptic ulcer disease. Aliment. Pharmacol. Ther. 1995, 9 (Suppl. 2), 59-69.

10. Hopkins, R.; Girardi, L.; Turney, E. Relationship between Helicobacter pylori eradication and reduced duodenal and gastric ulcer recurrence: A review. Gastroenterology 1996, 110, 1244. [CrossRef]

11. Amieva, M.; Peek, R.M., Jr. Pathobiology of Helicobacter pylori-induced gastric cancer. Gastroenterology 2016, 150, 64-78. [CrossRef] [PubMed]

12. Schoep, T.D.; Fulurija, A.; Good, F.; Lu, W.; Himbeck, R.P.; Schwan, C.; Choi, S.S.; Berg, D.E.; Mittl, P.R.; Benghezal, M.; et al. Surface properties of Helicobacter pylori urease complex are essential for persistence. PLoS ONE 2010, 5, e15042. [CrossRef] [PubMed]

13. Bode, G.; Malfertheiner, P.; Nilius, M.; Lehnhardt, G.; Ditschuneit, H. Ultrastructural localisation of urease in outer membrane and periplasm of Campylobacter pylori. J. Clin. Pathol. 1989, 42, 778-779. [CrossRef]

14. Athmann, C.; Zeng, N.; Kang, T.; Marcus, E.A.; Scott, D.R.; Rektorschek, M.; Buhmann, A.; Melchers, K.; Sachs, G. Local pH elevation mediated by the intra-bacterial urease of Helicobacter pylori co-cultured with gastric cells. J. Clin. Investig. 2000, 106, 339-347. [CrossRef] [PubMed]

15. Marcus, E.A.; Moshfegh, A.P.; Sachs, G.; Scott, D.R. The periplasmic alpha-carbonic anhydrase activity of Helicobacter pylori is essential for acid acclimation. J. Bacteriol. 2005, 187, 729-738. [CrossRef] [PubMed]

16. Weeks, D.L.; Eskandari, S.; Scott, D.R.; Sachs, G. A H ${ }^{+}$-gated urea channel: The link between Helicobacter pylori urease and gastric colonization. Science 2000, 287, 482-485. [CrossRef] [PubMed] 
17. Debowski, A.W.; Walton, S.M.; Chua, E.-G.; Tay, A.C.-Y.; Liao, T.; Lamichhane, B.; Himbeck, R.; Stubbs, K.A.; Marshall, B.J.; Fulurija, A.; et al. Helicobacter pylori gene silencing in vivo demonstrates urease is essential for chronic infection. PLoS Pathog. 2017, 13, e1006464. [CrossRef] [PubMed]

18. Lytton, S.D.; Fischer, W.; Nagel, W.; Haas, R.; Beck, F.X. Production of ammonium by Helicobacter pylori mediates occludin processing and disruption of tight junctions in Caco-2 cells. Microbiology 2005, 151 Pt 10, 3267-3276. [CrossRef]

19. Wroblewski, L.E.; Shen, L.; Ogden, S.; Romero-Gallo, J.; Lapierre, L.A.; Israel, D.A.; Turner, J.R.; Peek, R.M., Jr. Helicobacter pylori dysregulation of gastric epithelial tight junctions by urease-mediated myosin II activation. Gastroenterology 2009, 136, 236-246. [CrossRef] [PubMed]

20. Kuwahara, H.; Miyamoto, Y.; Akaike, T.; Kubota, T.; Sawa, T.; Okamoto, S.; Maeda, H. Helicobacter pylori urease suppresses bactericidal activity of peroxynitrite via carbon dioxide production. Infect. Immun. 2000, 68, 4378-4383. [CrossRef]

21. Olivera-Severo, D.; Uberti, A.F.; Marques, M.S.; Pinto, M.T.; Gomez-Lazaro, M.; Figueiredo, C.; Leite, M.; Carlini, C.R. A New Role for Helicobacter pylori Urease: Contributions to Angiogenesis. Front. Microbiol. 2017, 8, 1883. [CrossRef] [PubMed]

22. Valenzuela-Valderrama, M.; Cerda-Opazo, P.; Backert, S.; González, M.F.; Carrasco-Véliz, N.; Jorquera-Cordero, C.; Wehinger, S.; Canales, J.; Bravo, D.; Quest, A.F.G. The Helicobacter pylori Urease Virulence Factor Is Required for the Induction of Hypoxia-Induced Factor- $1 \alpha$ in Gastric Cells. Cancers 2019, 11, 799. [CrossRef] [PubMed]

23. De Jesus Souza, M.; de Moraes, J.A.; Da Silva, V.N.; Helal-Neto, E.; Uberti, A.F.; Scopel-Guerra, A.; Olivera-Severo, D.; Carlini, C.R.; Barja-Fidalgo, C. Helicobacter pylori urease induces pro-inflammatory effects and differentiation of human endothelial cells: Cellular and molecular mechanism. Helicobacter 2019, 24, e12573. [CrossRef] [PubMed]

24. Fan, X.; Gunasena, H.; Cheng, Z.; Espejo, R.; Crowe, S.E.; Ernst, P.B.; Reyes, V.E. Helicobacter pylori urease binds to class II MHC on gastric epithelial cells and induces their apoptosis. J. Immunol. 2000, 165, 1918-1924. [CrossRef]

25. Martínez, L.E.; Hardcastle, J.M.; Wang, J.; Pincus, Z.; Tsang, J.; Hoover, T.R.; Bansil, R.; Salama, N.R. Helicobacter pylori strains vary cell shape and flagellum number to maintain robust motility in viscous environments. Mol. Microbiol. 2016, 99, 88-110. [CrossRef]

26. Sycuro, L.K.; Pincus, Z.; Gutierrez, K.D.; Biboy, J.; Stern, C.A.; Vollmer, W.; Salama, N.R. Relaxation of peptidoglycan cross-linking promotes Helicobacter pylori's helical shape and stomach colonization. Cell 2010, 141, 822-833. [CrossRef]

27. Young, K.D. Bacterial morphology: Why have different shapes? Curr. Opin. Microbiol. 2007, 10, 596-600. [CrossRef]

28. Lee, A.; Fox, J.; Hazell, S. Pathogenicity of Helicobacter pylori: A perspective. Infect. Immun. 1993, 61, 1601-1610.

29. Sycuro, L.K.; Wyckoff, T.J.; Biboy, J.; Born, P.; Pincus, Z.; Vollmer, W.; Salama, N.R. Multiple peptidoglycan modification networks modulate Helicobacter pylori's cell shape, motility, and colonization potential. PLoS Pathog. 2012, 8, e1002603. [CrossRef]

30. Suerbaum, S. The complex flagella of gastric Helicobacter species. Trends Microbiol. 1995, 3, 168-170. [CrossRef]

31. Merrell, D.S.; Goodrich, M.L.; Otto, G.; Tompkins, L.S.; Falkow, S. pH-regulated gene expression of the gastric pathogen Helicobacter pylori. Infect. Immun. 2003, 71, 3529-3539. [CrossRef] [PubMed]

32. Kao, C.-Y.; Sheu, B.-S.; Sheu, S.-M.; Yang, H.-B.; Chang, W.-L.; Cheng, H.-C.; Wu, J.-J. Higher Motility Enhances Bacterial Density and Inflammatory Response in Dyspeptic Patients Infected with Helicobacter pylori. Helicobacter 2012, 17, 411-416. [CrossRef] [PubMed]

33. Forstnerič, V.; Ivičak-Kocjan, K.; Plaper, T.; Jerala, R.; Benčina, M. The role of the Cterminal D0 domain of flagellin in activation of Toll like receptor 5. PLoS Pathog. 2017, 13, e1006574. [CrossRef] [PubMed]

34. Ansari, S.; Yamaoka, Y. Helicobacter pylori BabA in adaptation for gastric colonization. World J. Gastroenterol. 2017, 23, 4158-4169. [CrossRef] [PubMed]

35. Ishijima, N.; Suzuki, M.; Ashida, H.; Ichikawa, Y.; Kanegae, Y.; Saito, I.; Borén, T.; Haas, R.; Sasakawa, C.; Mimuro, H. BabA-mediated adherence is a potentiator of the Helicobacter pylori type IV secretion system activity. J. Biol. Chem. 2011, 286, 25256-25264. [CrossRef] [PubMed] 
36. Toller, I.M.; Neelsen, K.J.; Steger, M.; Hartung, M.L.; Hottiger, M.O.; Stucki, M.; Kalali, B.; Gerhard, M.; Sartori, A.A.; Lopes, M.; et al. Carcinogenic bacterial pathogen Helicobacter pylori triggers DNA double-strand breaks and a DNA damage response in its host cells. Proc. Natl. Acad. Sci. USA 2011, 108, 14944-14949. [CrossRef] [PubMed]

37. Roche, N.; Angstrom, J.; Hurtig, M.; Larsson, T.; Boren, T.; Teneberg, S. Helicobacter pylori and complex gangliosides. Infect. Immun. 2004, 72, 1519-1529. [CrossRef]

38. Yamaoka, Y.; Kikuchi, S.; El Zimaity, H.M.T.; Gutierrez, O.; Osato, M.S.; Graham, D.Y. Importance of Helicobacter pylori oipA in clinical presentation, gastric inflammation, and mucosal interleukin 8 production. Gastroenterology 2002, 23, 414-424. [CrossRef]

39. Teymournejad, O.; Mobarez, A.M.; Hassan, Z.M.; Abadi, A.T.B. Binding of the Helicobacter pylori OipA causes apoptosis of host cells via modulation of Bax/Bcl-2 levels. Sci. Rep. 2017, 7, e8036. [CrossRef]

40. Gur, C.; Maalouf, N.; Gerhard, M.; Singer, B.B.; Emgård, J.; Temper, V.; Neuman, T.; Mandelboim, O.; Bachrach, G. The Helicobacter pylori HopQ outer membrane protein inhibits immune cell activities. OncoImmunology 2019, 8, e1553487. [CrossRef]

41. Tegtmeyer, N.; Wessler, S.; Backert, S. Role of the cag pathogenicity island encoded type IV secretion system in Helicobacter pylori pathogenesis. FEBS J. 2011, 278, 1190-1202. [CrossRef] [PubMed]

42. Hatakeyama, M. Helicobacter pylori and gastric carcinogenesis. J. Gastroenterol. 2009, 44, 239-248. [CrossRef] [PubMed]

43. Fischer, W.; Jürgen, P.L.; Buhrdorf, R.; Gebert, B.; Odenbreit, S.; Haas, R. Systematic mutagenesis of the Helicobacter pylori cag pathogenicity island: Essential genes for cagA translocation in host cells and induction of interleukin-8. Mol. Microbiol. 2001, 42, 1337-1348. [CrossRef] [PubMed]

44. Backert, S.; Meyer, T.F. Type IV secretion systems and their effectors in bacterial pathogenesis. Curr. Opin. Microbiol. 2006, 9, 207-217. [CrossRef]

45. Barrozo, R.M.; Cooke, C.L.; Hansen, L.M.; Lam, A.M.; Gaddy, J.A.; Johnson, E.M.; Cariaga, T.A.; Suarez, G.; Peek, R.M., Jr.; Cover, T.L.; et al. Functional plasticity in the type IV secretion system of Helicobacter pylori. PLoS Pathog. 2013, 9, e1003189. [CrossRef]

46. Gorrell, R.J.; Guan, J.; Xin, Y.; Tafreshi, M.A.; Hutton, M.L.; McGuckin, M.A.; Ferrero, R.L.; Kwok, T. A novel NOD1- and CagA-independent pathway of interleukin-8 induction mediated by the Helicobacter pylori type IV secretion system. Cell. Microbiol. 2013, 15, 554-570. [CrossRef]

47. Barrozo, R.M.; Hansen, L.M.; Lam, A.M.; Skoog, E.C.; Martin, M.E.; Cai, L.P.; Lin, Y.; Latoscha, A.; Suerbaum, S.; Canfield, D.R.; et al. CagY is an Immune-Sensitive Regulator of the Helicobacter pylori Type IV Secretion System. Gastroenterology 2016, 151, 1164-1175. [CrossRef]

48. Wang, X.; Ling, F.; Wang, H.; Yu, M.; Zhu, H.; Chen, C.; Qian, J.; Liu, C.; Zhang, Y.; Shao, S. The Helicobacter pylori Cag Pathogenicity Island Protein Cag1 is Associated with the Function of T4SS. Curr. Microbiol. 2016, 73, 22-30. [CrossRef]

49. Kwok, T.; Zabler, D.; Urman, S.; Rohde, M.; Hartig, R.; Wessler, S.; Misselwitz, R.; Berger, J.; Sewald, N.; Konig, W.; et al. Helicobacter exploits integrin for type IV secretion and kinase activation. Nature 2007, 449, 862-866. [CrossRef]

50. Wiedemann, T.; Hofbaur, S.; Loell, E.; Rieder, G. A C-terminal coiled-coil region of cagL is responsible for Helicobacter pylori-induced IL-8 expression. Eur. J. Microbiol. Immunol. 2016, 6, 186-196. [CrossRef]

51. Backert, S.; Tegtmeyer, N.; Selbach, M. The versatility of Helicobacter pylori CagA effector protein functions: The master key hypothesis. Helicobacter 2010, 15, 163-176. [CrossRef] [PubMed]

52. Higashi, H.; Tsutsumi, R.; Muto, S.; Sugiyama, T.; Azuma, T.; Asaka, M.; Hatakeyama, M. SHP-2 tyrosine phosphatase as an intracellular target of Helicobacter pylori CagA protein. Science 2002, 295, 683-686. [CrossRef] [PubMed]

53. Hatakeyama, M. Helicobacter pylori CagA and gastric cancer: A paradigm for hit- and-run carcinogenesis. Cell Host Microbe 2014, 15, 306-316. [CrossRef] [PubMed]

54. Lang, B.J.; Gorrell, R.J.; Tafreshi, M.; Hatakeyama, M.; Kwok, T.; Price, J.T. The Helicobacter pylori cytotoxin CagA is essential for suppressing host heat shock protein expression. Cell Stress Chaperones 2016, 21, 523-533. [CrossRef]

55. Axsen, W.S.; Styer, C.M.; Solnick, J.V. Inhibition of heat shock protein expression by Helicobacter pylori. Microb. Pathog. 2009, 47, 231-236. [CrossRef] 
56. De Bernard, M.; Moschioni, M.; Habermann, A.; Griffiths, G.; Montecucco, C. Cell vacuolization induced by Helicobacter pylori VacA cytotoxin does not depend on late endosomal SNAREs. Cell. Microbiol. 2002, 4, 11-18. [CrossRef]

57. Radin, J.N.; Gonzalez-Rivera, C.; Ivie, S.E.; McClain, M.S.; Cover, T.L. Helicobacter pylori VacA induces programmed necrosis in gastric epithelial cells. Infect. Immun. 2011, 79, 2535-2543. [CrossRef]

58. Akazawa, Y.; Isomoto, H.; Matsushima, K.; Kanda, T.; Minami, H.; Yamaghchi, N.; Taura, N.; Shiozawa, K.; Ohnita, K.; Takeshima, F.; et al. Endoplasmic reticulum stress contributes to Helicobacter pylori VacA-induced apoptosis. PLoS ONE 2013, 8, e82322. [CrossRef]

59. Luo, J.J.; Li, C.Y.; Liu, S.; Yu, W.; Tang, S.Y.; Cai, H.L.; Zhang, Y. Overexpression of Helicobacter pylori VacA $\mathrm{N}$-terminal fragment induces pro-inflammatory cytokine expression and apoptosis in human monocytic cell line through activation of NF-kappa B. Can. J. Microbiol. 2013, 59, 523-533. [CrossRef]

60. Zhao, Y.Q.; Guo, T.; Qian, J.M. Effects of broth culture filtrate protein of VacA + Helicobacter pylori on the proliferation and apoptosis of gastric epithelial cells. Chin. Med. J. 2013, 126, 2168-2173.

61. Zhu, P.; Xue, J.; Zhang, Z.-J.; Jia, Y.-P.; Tong, Y.-N.; Han, D.; Li, Q.; Xiang, Y.; Mao, X.-H.; Tang, B. Helicobacter pylori VacA induces autophagic cell death in gastric epithelial cells via the endoplasmic reticulum stress pathway. Cell Death Dis. 2017, 8, 3207. [CrossRef]

62. Wessler, S.; Schneider, G.; Backert, S. Bacterial serine protease HtrA as a promising new target for antimicrobial therapy? Cell Commun. Signal. 2017, 15, 4. [CrossRef]

63. Backert, S.; Bernegger, S.; Skórko-Glonek, J.; Wessler, S. Extracellular HtrA serine proteases: An emerging new strategy in bacterial pathogenesis. Cell. Microbiol. 2018, 20, e12845. [CrossRef]

64. Hoy, B.; Geppert, T.; Boehm, M.; Reisen, F.; Plattner, P.; Gadermaier, G.; Sewald, N.; Ferreira, F.; Briza, P.; Schneider, G.; et al. Distinct roles of secreted HtrA proteases from Gram-negative pathogens in cleaving the junctional protein and tumor suppressor E-cadherin. J. Biol. Chem. 2012, 287, 10115-10120. [CrossRef]

65. Hoy, B.; Löwer, M.; Weydig, C.; Carra, G.; Tegtmeyer, N.; Geppert, T.; Schröder, P.; Sewald, N.; Backert, S.; Schneider, G.; et al. Helicobacter pylori HtrA is a new secreted virulence factor that cleaves E-Cadherin to disrupt intercellular adhesion. EMBO J. 2010, 11, 798-804. [CrossRef]

66. Perna, A.M.; Rodrigues, T.; Schmidt, T.P.; Böhm, M.; Stutz, K.; Reker, D.; Pfeiffer, B.; Altmann, K.H.; Backert, S.; Wessler, S.; et al. Fragmented-Based De-Novo Design Reveals a Small-Molecule Inhibitor of Helicobacter pylori HtrA. Angew. Chem. Int. Ed. 2015, 54, 10244-10248. [CrossRef]

67. Schmidt, T.P.; Perna, A.M.; Fugmann, T.; Böhm, M.; Hiss, J.; Haller, S.; Götz, C.; Tegtmeyer, N.; Hoy, B.; Rau, T.T.; et al. Identification of E-cadherin signature motifs functioning as cleavage sites for Helicobacter pylori HtrA. Sci. Rep. 2016, 6, 23264. [CrossRef]

68. Tegtmeyer, N.; Moodley, Y.; Yamaoka, Y.; Pernitzsch, S.R.; Schmidt, V.; Traverso, F.R.; Schmidt, T.P.; Rad, R.; Yeoh, K.G.; Bow, H.; et al. Characterization of worldwide Helicobacter pylori strains reveals genetic conservation and essentiality of serine protease HtrA. Mol. Microbiol. 2016, 99, 925-944. [CrossRef]

69. Chan, A.O. E-cadherin in gastric cancer. World J. Gastroenterol. 2006, 12, 199-203. [CrossRef]

70. Tegtmeyer, N.; Wessler, S.; Necchi, V.; Rohde, M.; Harrer, A.; Rau, T.T.; Asche, C.I.; Boehm, M.; Loessner, H.; Figueiredo, C.; et al. Helicobacter pylori Employs a Unique Basolateral Type IV Secretion Mechanism for CagA Delivery. Cell Host Microbe 2017, 22, 552-560.e5. [CrossRef]

71. Wessler, S.; Backert, S. A novel basolateral type IV secretion model for the CagA oncoprotein of Helicobacter pylori. Microb. Cell 2018, 5, 60-62. [CrossRef]

72. Lekmeechai, S.; Su, Y.C.; Brant, M.; Alvarado-Kristensson, M.; Vallström, A.; Obi, I.; Arnqvist, A.; Riesbeck, K. Helicobacter pylori outer membrane vesicles protect the pathogen from reactive oxygen species of the respiratory burst. Front. Microbiol. 2018, 9, 1837. [CrossRef]

73. Macdonald, I.A.; Kuehn, M.J. Offense and defense: Microbial membrane vesicles play both ways. Res. Microbiol. 2012, 163, 607-618. [CrossRef]

74. Laughlin, R.C.; Mickum, M.; Rowin, K.; Adams, L.G.; Alaniz, R.C. Altered host immune responses to membrane vesicles from Salmonella and gram-negative pathogens. Vaccine 2015, 33, 5012-5019. [CrossRef]

75. Ko, S.H.; Rho, D.J.; Jeon, J.I.; Kim, Y.J.; Woo, H.A.; Kim, N.; Kim, J.M. Crude preparations of Helicobacter pylori outer membrane vesicles induce upregulation of Heme Oxygenase-1 via activating Akt-Nrf2 and mTOR-IkappaB kinase-NF-kappaB pathways in dendritic cells. Infect. Immun. 2016, 84, 2162-2174. [CrossRef] 
76. Shibayama, K.; Kamachi, K.; Nagata, N.; Yagi, T.; Nada, T.; Doi, Y.; Shibata, N.; Yokoyama, K.; Yamane, K.; Kato, H.; et al. A novel apoptosis-inducing protein from Helicobacter pylori. Mol. Microbiol. 2003, 147, 443-451. [CrossRef]

77. Kim, K.M.; Lee, S.G.; Park, M.G.; Song, J.Y.; Kang, H.L.; Lee, W.K.; Cho, M.J.; Rhee, K.H.; Youn, H.S.; Baik, S.C. $\gamma$-Glutamyltranspeptidase of Helicobacter pylori induces mitochondria-mediated apoptosis in AGS cells. Biochem. Biophys. Res. Commun. 2007, 355, 562-567. [CrossRef]

78. Valenzuela, M.; Bravo, D.; Canales, J.; Sanhueza, C.; Díaz, N.; Almarza, O.; Toledo, H.; Quest, A.F.G. Helicobacter pylori-induced loss of survivin and gastric cell viability is attributable to secreted bacterial gamma-glutamyl transpeptidase activity. J. Infect. Dis. 2013, 208, 1131-1141. [CrossRef]

79. Ling, S.S.M.; Khoo, L.H.B.; Hwang, L.A.; Yeoh, K.G.; Ho, B. Instrumental role of Helicobacter pylori $\gamma$-glutamyl transpeptidase in VacA-dependent vacuolation in gastric epithelial cells. PLoS ONE 2015, 10, e0131460. [CrossRef]

80. Odenbreit, S. Adherence properties of Helicobacter pylori: Impact on pathogenesis and adaptation to the host. Int. J. Med. Microbiol. 2005, 295, 317-324. [CrossRef]

81. Rhen, M.; Eriksson, S.; Clements, M.; Bergström, S.; Normark, S.J. The basis of persistent bacterial infections. Trends Microbiol. 2003, 11, 80-86. [CrossRef]

82. Aspholm, M.; Kalia, A.; Ruhl, S.; Schedin, S.; Arnqvist, A.; Lindén, S.; Sjöström, R.; Gerhard, M.; Semino-Mora, C.; Dubois, A.; et al. Helicobacter pylori adhesion to carbohydrates. Methods Enzymol. 2006, 417, 293-339.

83. Ilver, D.; Arnqvist, A.; Ogren, J.; Frick, I.M.; Kersulyte, D.; Incecik, E.T.; Berg, D.E.; Covacci, A.; Engstrand, L.; Borén, T. Helicobacter pylori adhesin binding fucosylated histo-blood group antigens revealed by retagging. Science 1998, 279, 373-377. [CrossRef]

84. Pride, D.T.; Blaser, M.J. Concerted evolution between duplicated genetic elements in Helicobacter pylori. J. Mol. Biol. 2002, 316, 629-642. [CrossRef]

85. Borén, T.; Falk, P.; Roth, K.A.; Larson, G.; Normark, S. Attachment of Helicobacter pylori to human gastric epithelium mediated by blood group antigens. Science 1993, 262, 1892-1895. [CrossRef]

86. Hennig, E.E.; Mernaugh, R.; Edl, J.; Cao, P.; Cover, T.L. Heterogeneity among Helicobacter pylori strains in expression of the outer membrane protein BabA. Infect. Immun. 2004, 72, 3429-3435. [CrossRef]

87. Aspholm-Hurtig, M.; Dailide, G.; Lahmann, M.; Kalia, A.; Ilver, D.; Roche, N.; Vikström, S.; Sjöström, R.; Lindén, S.; Bäckström, A.; et al. Functional adaptation of BabA, the H. pylori ABO blood group antigen binding adhesin. Science 2004, 305, 519-522. [CrossRef]

88. Pride, D.T.; Meinersmann, R.J.; Blaser, M.J. Allelic Variation within Helicobacter pylori babA and babB. Infect. Immun. 2001, 69, 1160-1171. [CrossRef]

89. Goodwin, A.C.; Weinberger, D.M.; Ford, C.B.; Nelson, J.C.; Snider, J.D.; Hall, J.D.; Paules, C.I.; Peek, R.M.; Forsyth, M.H. Expression of the Helicobacter pylori adhesin SabA is controlled via phase variation and the ArsRS signal transduction system. Microbiology 2008, 154, 2231-2240. [CrossRef]

90. Solnick, J.V.; Hansen, L.M.; Salama, N.R.; Boonjakuakul, J.K.; Syvanen, M. Modification of Helicobacter pylori outer membrane protein expression during experimental infection of rhesus macaques. Proc. Natl. Acad. Sci. USA 2004, 101, 2106-2111. [CrossRef]

91. Gerhard, M.; Lehn, N.; Neumayer, N.; Borén, T.; Rad, R.; Schepp, W.; Miehlke, S.; Classen, M.; Prinz, C. Clinical relevance of the Helicobacter pylori gene for blood-group antigen-binding adhesin. Proc. Natl. Acad. Sci. USA 1999, 96, 12778-12783. [CrossRef] [PubMed]

92. Olfat, F.O.; Zheng, Q.; Oleastro, M.; Voland, P.; Borén, T.; Karttunen, R.; Engstrand, L.; Rad, R.; Prinz, C.; Gerhard, M. Correlation of the Helicobacter pylori adherence factor BabA with duodenal ulcer disease in four European countries. FEMS Immunol. Med. Microbiol. 2005, 44, 151-156. [CrossRef]

93. Quintana-Hayashi, M.P.; Rocha, R.; Padra, M.; Thorell, A.; Jin, C.; Karlsson, N.G.; Roxo-Rosa, M.; Oleastro, M.; Lindén, S.K. BabA-mediated adherence of pediatric ulcerogenic $H$. pylori strains to gastric mucins at neutral and acidic pH. Virulence 2018, 9, 1699-1717. [CrossRef]

94. Benktander, J.; Barone, A.; Johansson, M.M.; Teneberg, S. Helicobacter pylori SabA binding gangliosides of human stomach. Virulence 2018, 9, 738-751. [CrossRef]

95. Sheu, B.S.; Odenbreit, S.; Hung, K.H.; Liu, C.P.; Sheu, S.M.; Yang, H.B.; Wu, J.J. Interaction between host gastric Sialy-Lewis-X and H. pylori SabA enhances H. pylori density in patients lacking gastric Lewis B antigen. Am. J. Gastroenterol. 2006, 101, 36-44. [CrossRef] 
96. Talarico, S.; Whitefeld, S.E.; Fero, J.; Haas, R.; Salama, N.R. Regulation of Helicobacter pylori adherence by gene conversion. Mol. Microbiol. 2012, 84, 1050-1061. [CrossRef]

97. Yamaoka, Y.; Ojo, O.; Fujimoto, S.; Odenbreit, S.; Haas, R.; Gutierrez, O.; El-Zimaity, H.M.; Reddy, R.; Arnqvist, A.; Graham, D.Y. Helicobacter pylori outer membrane proteins and gastroduodenal disease. Gut 2006, 55, 775-781. [CrossRef]

98. Yanai, A.; Maeda, S.; Hikiba, Y.; Shibata, W.; Ohmae, T.; Hirata, Y.; Ogura, K.; Yoshida, H.; Omata, M. Clinical relevance of Helicobacter pylori sabA genotype in Japanese clinical isolates. J. Gastroenterol. Hepatol. 2007, 22, 2228-2232. [CrossRef]

99. Gharibi, S.; Falsafi, T.; Alebouyeh, M.; Farzi, N.; Vaziri, F.; Zali, M.R. Relationship between histopathological status of the Helicobacter pylori infected patients and proteases of $H$. pylori in isolates carrying diverse virulence genotypes. Microb. Pathog. 2017, 110, 100-106. [CrossRef]

100. Mahdavi, J.; Sondén, B.; Hurtig, M.; Olfat, F.O.; Forsberg, L.; Roche, N.; Ångström, J.; Larsson, T.; Teneberg, S.; Karlsson, K.A. Helicobacter pylori SabA adhesin in persistent infection and chronic inflammation. Science 2002, 297, 573-578. [CrossRef]

101. Ota, H.; Nakayama, J.; Momose, M.; Hayama, M.; Akamatsu, T.; Katsuyama, T.; Graham, D.Y.; Genta, R.M. Helicobacter pylori infection produces reversible glycosylation changes to gastric mucins. Virchows Arch. 1998, 433, 419-426. [CrossRef] [PubMed]

102. Su, Y.L.; Huang, H.L.; Huang, B.S.; Chen, P.C.; Chen, C.S.; Wang, H.L.; Lin, P.H.; Chieh, M.S.; Wu, J.J.; Yang, J.C.; et al. Combination of OipA, BabA, and SabA as candidate biomarkers for predicting Helicobacter pylori-related gastric cancer. Sci. Rep. 2016, 6, 36442. [CrossRef] [PubMed]

103. Yamaoka, Y.; Kwon, D.H.; Graham, D.Y. A M(r) 34,000 pro-inflammatory outer membrane protein (oipA) of Helicobacter pylori. Proc. Natl. Acad. Sci. USA 2000, 97, 7533-7538. [CrossRef] [PubMed]

104. Horridge, D.N.; Begley, A.A.; Kim, J.; Aravindan, N.; Fan, K.; Forsyth, M.H. Outer inflammatory protein a (OipA) of Helicobacter pylori is regulated by host cell contact and mediates CagA translocation and interleukin-8 response only in the presence of a functional cag pathogenicity island type IV secretion system. Pathog. Dis. 2017, 75, ftx113. [CrossRef] [PubMed]

105. Yamaoka, Y.; Kita, M.; Kodama, T.; Imamura, S.; Ohno, T.; Sawai, N.; Ishimaru, A.; Imanishi, J.; Graham, D.Y. Helicobacter pylori infection in mice: Role of outer membrane proteins in colonization and inflammation. Gastroenterology 2002, 123, 1992-2004. [CrossRef] [PubMed]

106. Braga, L.L.B.C.; Batista, M.H.R.; de Azevedo, O.G.R.; da Silva Costa, K.C.; Gomes, A.D.; Rocha, G.A.; Queiroz, D.M.M. oipA "on" status of Helicobacter pylori is associated with gastric cancer in NorthEastern Brazil. BMC Cancer 2019, 19, 48. [CrossRef]

107. Sallas, M.L.; dos Santos, M.P.; Orcini, W.A.; David, E.B.; Peruquetti, R.L.; Payão, S.L.M.; Rasmussen, L.T. Status (on/off) of oipA gene: Their associations with gastritis and gastric cancer and geographic origins. Arch. Microbiol. 2019, 201, 93-97. [CrossRef]

108. Liu, J.; He, C.; Chen, M.; Wang, Z.; Xing, C.; Yuan, Y. Association of presence/absence and on/off patterns of Helicobacter pylori oipA gene with peptic ulcer disease and gastric cancer risks: A meta-analysis. BMC Infect. Dis. 2013, 13, 555. [CrossRef]

109. Franco, A.T.; Johnston, E.; Krishna, U.; Yamaoka, Y.; Israel, D.A.; Nagy, T.A.; Wroblewski, L.E.; Piazuelo, M.B.; Correa, P.; Peek, R.M., Jr. Regulation of gastric carcinogenesis by Helicobacter pylori virulence factors. Cancer Res. 2008, 68, 379-387. [CrossRef]

110. Yamaoka, Y. Mechanisms of disease: Helicobacter pylori virulence factors. Nat. Rev. Gastroenterol. Hepatol. 2010, 7, 629-641. [CrossRef]

111. Teymournejad, O.; Mobarez, A.M.; Hassan, Z.M.; Moazzeni, S.M.; Ahmadabad, H.N. In vitro suppression of dendritic cells by Helicobacter pylori OipA. Helicobacter 2014, 19, 136-143. [CrossRef] [PubMed]

112. Backert, S.; Selbach, M. Role of type IV secretion in Helicobacter pylori pathogenesis. Cell. Microbiol. 2008, 10, 1573-1581. [CrossRef] [PubMed]

113. Cao, P.; Cover, T.L. Two different families of hopQ alleles in Helicobacter pylori. J. Clin. Microbiol. 2002, 40, 4504-4511. [CrossRef] [PubMed]

114. Koniger, V.; Holsten, L.; Harrison, U.; Busch, B.; Loell, E.; Zhao, Q.; Bonsor, D.A.; Roth, A.; Kengmo-Tchoupa, A.; Smith, S.I.; et al. Helicobacter pylori exploits human CEACAMs via HopQ fot adherence and translocation of CagA. Nat. Microbiol. 2016, 2, 16188. [CrossRef] [PubMed] 
115. Feige, M.H.; Sokolova, O.; Pickenhahn, A.; Maubach, G.; Naumann, M. HopQ impacts the integrin alpha5beta1-independent NF-kappaB activation by Helicobacter pylori in CEACAM expressing cells. Int. J. Med. Microbiol. 2018, 308, 527-533. [CrossRef]

116. Bonsor, D.A.; Zhao, Q.; Schmidinger, B.; Weiss, E.; Wang, J.; Deredge, D.; Beadenkopf, R.; Dow, B.; Fischer, W.; Beckett, D.; et al. The Helicobacter pylori adhesin protein HopQ exploits the dimer interface of human CEACAMs to facilitate translocation of the oncoprotein CagA. EMBO J. 2018, 37, e98664. [CrossRef]

117. Cao, P.; Lee, K.J.; Blaser, M.J.; Cover, T.L. Analysis of hopQ alleles in East Asian and Western strains of Helicobacter pylori. FEMS Microbiol. Lett. 2005, 251, 37-43. [CrossRef]

118. Leylabadlo, H.E.; Yekani, M.; Ghotaslou, R. Helicobacter pylori hopQ alleles (type I and II) in gastric cancer. Biomed. Rep. 2016, 4, 601-604. [CrossRef]

119. Yakoob, J.; Abbas, Z.; Khan, R.; Salim, S.A.; Awan, S.; Abrar, A.; Jafri, W. Helicobacter pylori outer membrane protein $Q$ allele distribution is associated with distinct pathologies in Pakistan. Infect. Genet. Evol. 2016, 37, 57-62. [CrossRef]

120. Abadi, A.T.B.; Mobarez, A.M. High Prevalence of Helicobacter pylori hopQ II Genotype Isolated from Iranian Patients with Gastroduodenal Disorders. J. Pathog. 2014, 2014, 871601. [CrossRef]

121. Javaheri, A.; Kruse, T.; Moonens, K.; Mejias-Luque, R.; Debraekeleer, A.; Asche, C.I.; Tegtmeyer, N.; Kalali, B.; Bach, N.C.; Sieber, S.A.; et al. Helicobacter pylori adhesin HopQ engages in a virulence-enhancing interaction with human CEACAMs. Nat. Microbiol. 2016, 2, 16189. [CrossRef] [PubMed]

122. Grzeszczuk, M.J.; Bocian-Ostrzycka, K.M.; Banaśa, A.M.; Roszczenko-Jasinska, P.; Malinowska, A.; Stralova, H.; Haas, R.; Meyer, T.F.; Jagusztyn-Krynick, E.K. Thiol-oxidoreductase HP0231 of Helicobacter pylori impacts HopQ-dependent CagA translocation. Int. J. Med. Microbiol. 2018, 308, 977-985. [CrossRef] [PubMed]

123. Yakoob, J.; Abbas, Z.; Ahmad, Z.; Tariq, K.; Awan, S.; Mustafa, K.; Khan, R. Gastric lymphoma: Association with Helicobacter pylori outer membrane protein Q (HopQ) and cytotoxic-pathogenicity activity island (CPAI) genes. Epidemiol. Infect. 2017, 145, 3468-3476. [CrossRef] [PubMed]

124. Schuelein, R.; Everingham, P.; Kwok, T. Integrin-mediated type IV secretion by Helicobacter: What makes it tick? Trends Microbiol. 2011, 19, 211-216. [CrossRef]

125. Backert, S.; Tegtmeyer, N.; Fischer, W. Composition, structure and function of the Helicobacter pylori cag pathogenicity island encoded type IV secretion system. Future Microbiol. 2015, 10, 955-965. [CrossRef]

126. Frick-Cheng, A.E.; Pyburn, T.M.; Voss, B.J.; McDonald, W.H.; Ohi, M.D.; Cover, T.L. Molecular and structural analysis of the Helicobacter pylori cag type IV secretion system core complex. mBio 2016, 7, e02001-e02015. [CrossRef]

127. Nguyen, L.T.; Uchida, T.; Tsukamoto, Y.; Trinh, T.D.; Ta, L.; Mai, H.B.; Le, H.S.; Ho, D.Q.; Hoang, H.H.; Matsuhisa, T.; et al. Clinical relevance of cagPAI intactness in Helicobacter pylori isolates from Vietnam. Eur. J. Clin. Microbiol. Inf. Dis. 2010, 29, 651-660. [CrossRef]

128. Sanchez-Zauco, N.A.; Torres, J.; Perez-Figueroa, G.E.; Alvarez-Arellano, L.; Camorlinga-Ponce, M.; Gómez, A.; Giono-Cerezo, S.; Maldonado-Bernal, C. Impact of cagPAI and T4SS on the Inflammatory Response of Human Neutrophils to Helicobacter pylori Infection. PLoS ONE 2013, 8, e64623. [CrossRef]

129. Wroblewski, L.E.; Peek, R.M., Jr. Helicobacter pylori: Pathogenic enablers-toxic relationships in the stomach. Nat. Rev. Gastroenterol. Hepatol. 2016, 13, 317-318. [CrossRef]

130. Ahmadzadeh, A.; Ghalehnoei, H.; Farzi, N.; Yadegar, A.; Alebouyeh, M.; Aghdaei, H.A.; Molaei, M.; Zali, M.R.; Pour Hossein Gholi, M.A. Association of CagPAI integrity with severeness of Helicobacter pylori infection in patients with gastritis. Pathol. Biol. 2015, 63, 252-257. [CrossRef]

131. Kauser, F.; Khan, A.A.; Hussain, M.A.; Carroll, I.M.; Ahmad, N.; Tiwari, S.; Shouche, Y.; Das, B.; Alam, M.; Ali, S.M.; et al. The cag pathogenicity island of Helicobacter pylori is disrupted in the majority of patient isolates from different human populations. J. Clin. Microbiol. 2004, 42, 5302-5308. [CrossRef] [PubMed]

132. Kusters, J.G.; van Vliet, A.H.; Kuipers, E.J. Pathogenesis of Helicobacter pylori infection. Clin. Microbiol. Rev. 2006, 19, 449-490. [CrossRef] [PubMed]

133. Olbermann, P.; Josenhans, C.; Moodley, Y.; Uhr, M.; Stamer, C.; Vauterin, M.; Suerbaum, S.; Achtman, M.; Linz, B. A global overview of the genetic and functional diversity in the Helicobacter pylori cag pathogenicity island. PLoS Genet. 2010, 6, e1001069. [CrossRef] [PubMed] 
134. Markovska, R.; Boyanova, L.; Yordanov, D.; Stankova, P.; Gergova, G.; Mitov, I. Status of Helicobacter pylori cag pathogenicity island (cagPAI) integrity and significance of its individual genes. Infect. Genet. Evol. 2018, 59, 167-171. [CrossRef] [PubMed]

135. Yao, Y.; Shen, Y.; Zhu, L.; Ni, Y.; Wang, H.; Shao, S. Preliminary study and bioinformatics analysis on the potential role of CagQ in type IV secretion system of H. pylori. Microb. Pathog. 2018, 116, 1-7. [CrossRef] [PubMed]

136. Conradi, J.; Tegtmeyer, N.; Wozna, M.; Wissbrock, M.; Michalek, C.; Gagell, C.; Cover, T.L.; Frank, R.; Sewald, N.; Backert, S. An RGD helper sequence in CagL of Helicobacter pylori assists in interactions with integrins and injection of CagA. Front. Cell. Infect. Microbiol. 2012, 2, 70. [CrossRef]

137. Saha, A.; Backert, S.; Hammond, C.E.; Gooz, M.; Smolka, A.J. Helicobacter pylori CagL activates ADAM17 to induce repression of the gastric H, K-ATPase alpha subunit. Gastroenterology 2010, 139, 239-248. [CrossRef]

138. Tegtmeyer, N.; Hartig, R.; Delahay, R.M.; Rohde, M.; Brandt, S.; Conradi, J.; Takahashi, S.; Smolka, A.J.; Sewald, N.; Backert, S. A small fibronectin-mimicking protein from bacteria induces cell spreading and focal adhesion formation. J. Biol. Chem. 2010, 285, 23515-23526. [CrossRef]

139. Román Roman, A.; Martínez Santos, V.I.; Castañón Sánchez, C.A.; Albañil Muñoz, A.J.; Mendoza, P.G.; Soto Flores, D.G.; Martínez Carrillo, D.N.; Tilapa, G.F. CagL polymorphisms D58/K59 are predominant in Helicobacter pylori strains isolated from Mexican patients with chronic gastritis. Gut Pathog. 2019, 11, 5. [CrossRef]

140. Yadegar, A.; Mohabati Mobarez, A.; Zali, M.R. Genetic diversity and amino acid sequence polymorphism in Helicobacter pylori CagL hypervariable motif and its association with virulence markers and gastroduodenal diseases. Cancer Med. 2019, 8, 1619-1632. [CrossRef]

141. Tafreshi, M.; Zwickel, N.; Gorrell, R.J.; Kwok, T. Preservation of Helicobacter pylori CagA translocation and host cell pro-inflammatory responses in the face of CagL hyper variability at amino acid residues 58/59. PLoS ONE 2015, 10, e0133531. [CrossRef] [PubMed]

142. Gorrell, R.J.; Zwickel, N.; Reynolds, J.; Bulach, D.; Kwok, T. Helicobacter pylori CagL hypervariable motif: A global analysis of geographical diversity and association with gastric cancer. J. Infect. Dis. 2016, 213, 1927-1931. [CrossRef] [PubMed]

143. Covacci, A.; Rappuoli, R. Tyrosine phosphorylated bacterial proteins: Trojan horses for the host cell. J. Exp. Med. 2000, 191, 587-592. [CrossRef] [PubMed]

144. Shaffer, C.L.; Gaddy, J.A.; Loh, J.T.; Johnson, E.M.; Hill, S.; Hennig, E.E.; McClain, M.S.; McDonald, W.H.; Cover, T.L. Helicobacter pylori exploits a unique repertoire of type IV secretion system components for pilus assembly at the bacteria-host cell interface. PLoS Pathog. 2011, 7, e1002237. [CrossRef] [PubMed]

145. Viala, J.; Chaput, C.; Boneca, I.G.; Cardona, A.; Girardin, S.E.; Moran, A.P.; Athman, R.; Memet, S.; Huerre, M.R.; Coyle, A.J.; et al. Nod1 responds to peptidoglycan delivered by the Helicobacter pylori cag pathogenicity island. Nat. Immunol. 2004, 5, 1166-1174. [CrossRef] [PubMed]

146. Varga, M.G.; Shaffer, C.L.; Sierra, J.C.; Suarez, G.; Piazuelo, M.B.; Whitaker, M.E.; Romero-Gallo, J.; Krishna, U.S.; Delgado, A.; Gomez, M.A.; et al. Pathogenic Helicobacter pylori strains translocate DNA and activate TLR9 via the cancer-associated cag type IV secretion system. Oncogene 2016, 35, 6262-6269. [CrossRef] [PubMed]

147. Stein, S.C.; Faber, E.; Bats, S.H.; Murillo, T.; Speidel, Y.; Coombs, N.; Josenhans, C. Helicobacter pylori modulates host cell responses by CagT4SS-dependent translocation of an intermediate metabolite of LPS inner core heptose biosynthesis. PLoS Pathog. 2017, 13, 1-32. [CrossRef]

148. Zhou, P.; She, Y.; Dong, N.; Li, P.; He, H.; Borio, A.; Wu, Q.; Lu, S.; Ding, X.; Cao, Y.; et al. Alpha-kinase 1 is a cytosolic innate immune receptor for bacterial ADP heptose. Nature 2018, 561, 122-126. [CrossRef]

149. Jiménez-Soto, L.F.; Haas, R. The CagA toxin of Helicobacter pylori: Abundant production but relatively low amount translocated. Sci. Rep. 2016, 6, 23227. [CrossRef]

150. Clague, M.J.; Urbé, S. Ubiquitin: Same molecule, different degradation pathways. Cell 2010, 143, 682-685. [CrossRef]

151. Abdullah, M.; Greenfeld, L.K.; Bronte-Tinkew, D.; Capurro, M.I.; Rizzuti, D.; Jones, N.L. VacA promotes CagA accumulation in gastric epithelial cells during Helicobacter pylori infection. Sci. Rep. 2019, 9, 38. [CrossRef] [PubMed]

152. Tohidpour, A. CagA-mediated pathogenesis of Helicobacter pylori. Microb. Pathog. 2016, 93, 44-55. [CrossRef] [PubMed] 
153. Zanotti, G.; Cendron, L. Structural and functional aspects of the Helicobacter pylori secretome. World J. Gastroenterol. 2014, 20, 1402-1423. [CrossRef] [PubMed]

154. Mimuro, H.; Suzuki, T.; Tanaka, J.; Asahi, M.; Haas, R.; Sasakawa, C. Grb2 is a key mediator of Helicobacter pylori CagA protein activities. Mol. Cell 2002, 10, 745-755. [CrossRef]

155. Saito, Y.; Murata-Kamiya, N.; Hirayama, T.; Ohba, Y.; Hatakeyama, M. Conversion of Helicobacter pylori CagA from senescence inducer to oncogenic driver through polarity-dependent regulation of p21. J. Exp. Med. 2010, 207, 2157-2174. [CrossRef]

156. Li, N.; Feng, Y.; Hu, Y.; He, C.; Xie, C.; Ouyang, Y.; Artim, S.C.; Huang, D.; Zhu, Y.; Luo, Z.; et al. Helicobacter pylori CagA promotes epithelial mesenchymal transition in gastric carcinogenesis via triggering oncogenic YAP pathway. J. Exp. Clin. Cancer Res. 2018, 37, 280. [CrossRef]

157. Higashi, H.; Tsutsumi, R.; Fujita, A.; Yamazaki, S.; Asaka, M.; Azuma, T.; Hatakeyama, M. Biological activity of the Helicobacter pylori virulence factor CagA is determined by variation in the tyrosine phosphorylation sites. Proc. Natl. Acad. Sci. USA 2002, 99, 14428-14433. [CrossRef]

158. Li, Q.; Liu, J.; Gong, Y.; Yuan, Y. Association of CagA EPIYA-D or EPIYA-C phosphorylation sites with peptic ulcer and gastric cancer risks: A meta-analysis. Medicine 2017, 96, e6620. [CrossRef]

159. Zhang, X.S.; Tegtmeyer, N.; Traube, L.; Jindal, S.; Perez-Perez, G.; Sticht, H.; Backert, S.; Blaser, M.J. A specific A/T polymorphism in Western tyrosine phosphorylation B-motifs regulates Helicobacter pylori CagA epithelial cell interactions. PLoS Pathog. 2015, 11, e1004621. [CrossRef]

160. Choi, S.I.; Yoon, C.; Park, M.R.; Lee, D.; Kook, M.C.; Lin, J.X.; Kang, J.H.; Ashktorab, H.; Smoot, D.T.; Yoon, S.S.; et al. CDX1 expression induced by CagA-expressing Helicobacter pylori promotes gastric tumorigenesis. Mol. Cancer Res. 2019, 17, 2169-2183. [CrossRef]

161. Grainger, S.; Hryniuk, A.; Lohnes, D. Cdx1 and Cdx2 exhibit transcriptional specificity in the intestine. PLoS ONE 2013, 8, e54757. [CrossRef] [PubMed]

162. Wroblewski, L.E.; Choi, E.; Petersen, C.; Delgado, A.G.; Piazuelo, M.B.; Romero-Gallo, J.; Lantz, T.L.; Zavros, Y.; Coffey, R.J.; Goldenring, J.R.; et al. Targeted mobilization of Lrig1+ gastric epithelial stem cell populations by a carcinogenic Helicobacter pylori type IV secretion system. Proc. Nat. Acad. Sci. USA 2019, 116, 19652-19658. [CrossRef] [PubMed]

163. Tsugawa, H.; Suzuki, H.; Saya, H.; Hatakeyama, M.; Hirayama, T.; Hirata, K.; Nagano, O.; Matsuzaki, J.; Hibi, T. Reactive oxygen species-induced autophagic degradation of Helicobacter pylori CagA is specifically suppressed in cancer stem-like cells. Cell Host Microbe 2012, 12, 764-777. [CrossRef] [PubMed]

164. Terebiznik, M.R.; Raju, D.; Vázquez, C.L.; Torbricki, K.; Kulkarni, R.; Blanke, S.R.; Yoshimori, T.; Colombo, M.I.; Jones, N.L. Efect of Helicobacter pylori's vacuolating cytotoxin on the autophagy pathway in gastric epithelial cells. Autophagy 2009, 5, 370-379. [CrossRef] [PubMed]

165. Ricci, V. Relationship between VacA toxin and host cell autophagy in Helicobacter pylori infection of the human stomach: A few answers, many questions. Toxins 2016, 8, 203. [CrossRef]

166. Atherton, J.C.; Cao, P.; Peek, R.M.; Tummuru, M.K.; Blaser, M.J.; Cover, T.L. Mosaicism in vacuolating cytotoxin alleles of Helicobacter pylori association of specific VacA types with cytotoxin production and peptic ulceration. J. Biol. Chem. 1995, 270, 17771-17777. [CrossRef]

167. Rhead, J.L.; Letley, D.P.; Mohammadi, M.; Hussein, N.; Mohagheghi, M.A.; Eshagh Hosseini, M.; Atherton, J.C. A new Helicobacter pylori vacuolating cytotoxin determinant, the intermediate region, is associated with gastric cancer. Gastroenterology 2007, 133, 926-936. [CrossRef]

168. Bridge, D.R.; Merrell, D.S. Polymorphism in the Helicobacter pylori CagA and VacA toxins and disease. Gut Microbes 2003, 4, 101-117. [CrossRef]

169. Chung, C.; Olivares, A.; Torres, E.; Yilmaz, O.; Cohen, H.; Perez-Perez, G. Diversity of VacA intermediate region among Helicobacter pylori strains from several regions of the world. J. Clin. Microbiol. 2010, 48, 690-696. [CrossRef]

170. McClain, M.S.; Cao, P.; Iwamoto, H.; Vinion-Dubiel, A.D.; Szabo, G.; Shao, Z.; Cover, T.L. A 12 amino acid segment, present in type s2 but not type s1 Helicobacter pylori VacA proteins, abolishes cytotoxin activity and alters membrane channel formation. J. Bacteriol. 2001, 183, 6499-6508. [CrossRef]

171. Trang, T.T.H.; Binh, T.T.; Yamaoka, Y. Relationship between vacA Types and Development of Gastroduodenal Diseases. Toxins 2016, 8, 182. [CrossRef] [PubMed] 
172. Atherton, J.C.; Sharp, P.M.; Cover, T.L.; Gonzalez-Valencia, G.; Peek, R.M., Jr.; Thompson, S.A.; Hawkey, C.J.; Blaser, M.J. Vacuolating cytotoxin (vacA) alleles of Helicobacter pylori comprise two geographically widespread types, $\mathrm{m} 1$ and m2, and have evolved through limited recombination. Curr. Microbiol. 1999, 39, 211-218. [CrossRef] [PubMed]

173. Forsyth, M.H.; Atherton, J.C.; Blaser, M.J.; Cover, T.L. Heterogeneity in levels of vacuolating cytotoxin gene $($ vacA) transcription among Helicobacter pylori strains. Infect. Immun. 1998, 66, e3088-e3094.

174. Matos, J.I.; de Sousa, H.A.; Marcos-Pinto, R.; Dinis-Ribeiro, M. Helicobacter pylori CagA and VacA genotypes and gastric phenotype: A meta-analysis. Eur. J. Gastroenterol. Hepatol. 2013, 25, 1431-1441. [CrossRef] [PubMed]

175. Liu, X.; He, B.; Cho, W.C.; Pan, Y.; Chen, J.; Ying, H.; Wang, F.; Lin, K.; Peng, H.; Wang, S. A systematic review on the association between the Helicobacter pylori vacA i genotype and gastric disease. FEBS Open Bio 2016, 6, 409-417. [CrossRef]

176. Sezikli, M.; Guliter, S.; Apan, T.Z.; Aksoy, A.; Keles, H.; Ozkurt, Z.N. Frequencies of serum antibodies to Helicobacter pylori CagA and VacA in a Turkish population with various gastroduodenal diseases. Int. J. Clin. Pract. 2006, 60, 1239-1243. [CrossRef]

177. Li, Q.; Liu, J.; Gong, Y.; Yuan, Y. Serum VacA antibody is associated with risks of peptic ulcer and gastric cancer: A meta-analysis. Microb. Pathog. 2016, 99, 220-228. [CrossRef]

178. Butt, J.; Varga, M.G.; Blot, W.J.; Teras, L.; Visvanathan, K.; Le Marchand, L.; Haiman, C.; Chen, Y.; Bao, Y.; Sesso, H.D.; et al. Serologic response to Helicobacter pylori proteins associated with risk of colorectal cancer among diverse populations in the United States. Gastroenterology 2019, 156, 175-186. [CrossRef]

179. Ji, X.; Fernandez, T.; Burroni, D.; Pagliaccia, C.; Atherton, J.C.; Reyrat, J.M.; Rappuoli, R.; Telford, J.L. Cell specificity of Helicobacter pylori cytotoxin is determined by a short region in the polymorphic midregion. Infect. Immun. 2000, 68, 3754-3757. [CrossRef]

180. Wang, W.-C.; Wang, H.-J.; Kuo, C.-H. Two distinctive cell binding patterns by vacuolating toxin fused with glutathione $\mathrm{S}$ transferase: One high affinity $\mathrm{m} 1$ specific binding and the other lower affinity binding for variant $\mathrm{m}$ forms. Biochemistry 2001, 40, 11887-11896. [CrossRef]

181. Terebiznik, M.R.; Vazquez, C.L.; Torbicki, K.; Banks, D.; Wang, T.; Hong, W.; Blanke, S.R.; Colombo, M.I.; Jones, N.L. Helicobacter pylori VacA Toxin Promotes Bacterial Intracellular Survival in Gastric Epithelial Cells. Infect. Immun. 2006, 74, 6599-6614. [CrossRef] [PubMed]

182. Capurro, M.I.; Greenfield, L.K.; Prashar, A.; Xia, S.; Abdullah, M.; Wong, H.; Zhong, X.Z.; Bertaux-Skeirik, N.; Chakrabarti, J.; Siddiqui, I.; et al. VacA generates a protective intracellular reservoir for Helicobacter pylori that is eliminated by activation of the lysosomal calcium channel TRPML1. Nat. Microbiol. 2019, 4, 1411-1423. [CrossRef] [PubMed]

183. Clausen, T.; Southan, C.; Ehrmann, M. The HtrA family of proteases: Implications for protein composition and cell fate. Mol. Cell 2002, 10, 443-455. [CrossRef]

184. Clausen, T.; Kaiser, M.; Huber, R.; Ehrmann, M. HTRA proteases: Regulated proteolysis in protein quality control. Nat. Rev. Mol. Cell Biol. 2011, 12, 152-162. [CrossRef]

185. Page, M.J.; Di Cera, E. Evolution of peptidase diversity. J. Biol. Chem. 2008, 283, 30010-30014. [CrossRef]

186. Merdanovic, M.; Clausen, T.; Kaiser, M.; Huber, R.; Ehrmann, M. Protein quality control in the bacterial periplasm. Annu. Rev. Microbiol. 2011, 65, 149-168. [CrossRef]

187. Gottesman, S.; Wickner, S.; Maurizi, M.R. Protein quality control: Triage by chaperone and proteases. Genes Dev. 1997, 11, 815-823. [CrossRef]

188. Ingmer, H.; Brøndsted, L. Proteases in bacterial pathogenesis. Res. Microbiol. 2009, 160, 704-710. [CrossRef]

189. Frees, D.; Brøndsted, L.; Ingmer, H. Bacterial proteases and virulence. Subcell. Biochem. 2013, 66, 161-192.

190. Skórko-Glonek, J.; Figaj, D.; Zarzecka, U.; Przepiora, T.; Renke, J.; Lipinska, B. The extracellular bacterial HtrA proteins as potential therapeutic targets and vaccine candidates. Curr. Med. Chem. 2017, 24, 2174-2204. [CrossRef]

191. Zarzecka, U.; Modrak-Wójcik, A.; Figaj, D.; Apanowicz, M.; Lesner, A.; Bzowska, A.; Lipinska, B.; Zawilak-Pawlik, A.; Backert, S.; Skorko-Glonek, J. Properties of the HtrA Protease from Bacterium Helicobacter pylori Whose Activity Is Indispensable for Growth Under Stress Conditions. Front. Microbiol. 2019, 10, 961. [CrossRef] [PubMed]

192. Hoy, B.; Brandstetter, H.; Wessler, S. The stability and activity of recombinant Helicobacter pylori HtrA under stress conditions. J. Basic Microbiol. 2013, 53, 402-409. [CrossRef] [PubMed] 
193. Harrer, A.; Boehm, M.; Backert, S.; Tegtmeyer, N. Overexpression of serine protease HtrA enhances disruption of adherens junctions, paracellular transmigration and type IV secretion of CagA by Helicobacter pylori. Gut Pathog. 2017, 9, 40. [CrossRef] [PubMed]

194. Van der Pol, E.; Boing, A.N.; Harrison, P.; Sturk, A.; Nieuwland, R. Classification, functions, and clinical relevance of extracellular vesicles. Pharmacol. Rev. 2012, 64, 676-705. [CrossRef]

195. Kim, J.H.; Lee, J.; Park, J.; Gho, Y.S. Gram-negative and Gram-positive bacterial extracellular vesicles. Semin. Cell Dev. Biol. 2015, 40, 97-104. [CrossRef]

196. Deatherage, B.L.; Lara, J.C.; Bergsbaken, T.; Rassoulian Barrets, S.L.; Lara, S.; Cookson, B.T. Biogenesis of bacterial outer membrane vesicles. Mol. Microbiol. 2009, 72, 1395-1407. [CrossRef]

197. Olofsson, A.; Vallström, A.; Petzold, K.; Tegtmeyer, N.; Schleucher, J.; Carlsson, S.; Haas, R.; Backert, S.; Wai, S.N.; Gröbner, G.; et al. Biochemical and functional characterization of Helicobacter pylori vesicles. Mol. Microbiol. 2010, 77, 1539-1555. [CrossRef]

198. Unal, C.M.; Schaar, V.; Riesbeck, K. Bacterial outer membrane vesicles in disease and preventive medicine. Semin. Immunopathol. 2011, 33, 395-408. [CrossRef]

199. Fiocca, R.; Necchi, V.; Sommi, P.; Ricci, V.; Telford, J.; Cover, T.L.; Solcia, E. Release of Helicobacter pylori vacuolating cytotoxin by both a specific secretion pathway and budding of outer membrane vesicles. Uptake of released toxin and vesicles by gastric epithelium. J. Pathol. 1999, 188, 220-226. [CrossRef]

200. Keenan, J.; Day, T.; Neal, S.; Cook, B.; Perez-Perez, G.; Allardyce, R.; Bagshaw, P. A role for the bacterial outer membrane in the pathogenesis of Helicobacter pylori infection. FEMS Microbiol. Lett. 2000, 182, 259-264. [CrossRef]

201. Mullaney, E.; Brown, P.A.; Smith, S.M.; Botting, C.H.; Yamaoka, Y.Y.; Terres, A.M.; Kelleher, D.P.; Windle, H.J. Proteomic and functional characterization of the outer membrane vesicles from the gastric pathogen Helicobacter pylori. Proteom. Clin. Appl. 2009, 3, 785-796. [CrossRef] [PubMed]

202. Olofsson, A.; Skalman, L.N.; Obi, I.; Lundmark, R.; Arnqvist, A. Uptake of Helicobacter pylori Vesicles Is Facilitated by Clathrin Dependent and Clathrin-Independent Endocytic Pathways. mBio 2014, 5, e00979-14. [CrossRef] [PubMed]

203. Parker, H.; Keenan, J.I. Composition and function of Helicobacter pylori outer membrane vesicles. Microbes Infect. 2012, 14, 9-16. [CrossRef] [PubMed]

204. Ellis, T.N.; Kuehn, M.J. Virulence and immunomodulatory roles of bacterial outer membrane vesicles. Microbiol. Mol. Biol. Rev. 2010, 74, 81-94. [CrossRef]

205. Winter, J.L.D.; Rhead, J.; Atherton, J.; Robinson, K. Helicobacter pylori membrane vesicles stimulate innate proand anti-inflammatory responses and induce apoptosis in Jurkat T cells. Infect. Immun. 2014, 82, 1372-1381. [CrossRef]

206. Choi, H.I.; Choi, J.P.; Seo, J.; Kim, B.J.; Rho, M.; Han, J.K.; Kim, J.G. Helicobacter pylori-derived extracellular vesicles increased in the gastric juices of gastric adenocarcinoma patients and induced inflammation mainly via specific targeting of gastrin epithelial cells. Exp. Mol. Med. 2017, 49, e330. [CrossRef]

207. Chitcholtan, K.; Hampton, M.B.; Keenan, J.I. Outer membrane vesicles enhance the carcinogenic potential of Helicobacter pylori. Carcinogenesis 2008, 29, 2400-2405. [CrossRef]

208. Hanigan, M.H. gamma-Glutamyl transpeptidase, a glutathionase: Its expression and function in carcinogenesis. Chem. Biol. Interact. 1998, 111, 333-342. [CrossRef]

209. Chevalier, C.; Thiberge, J.M.; Ferrero, R.; Labigne, A. Essential role of Helicobacter pylori g-glutamyltranspeptidase for the colonization of the gastric mucosa of mice. Mol. Microbiol. 1999, 31, 1359-1372. [CrossRef]

210. Mcgovern, K.J.; Blanchard, T.G.; Gutierrez, J.A.; Czinn, S.J.; Krakowka, S.; Youngman, P. g-glutamyltransferase is a Helicobacter pylori virulence factor but is not essential for colonization. Infect. Immun. 2001, 69, 4168-4173. [CrossRef]

211. Wüstner, S.; Anderl, F.; Wanisch, A.; Sachs, C.; Steiger, K.; Nerlich, A.; Vieth, M.; Mejías-Luque, R.; Gerhard, M. Helicobacter pylori $\gamma$-glutamyl transferase contributes to colonization and diferential recruitment of $\mathrm{T}$ cells during persistence. Sci. Rep. 2017, 7, 13636. [CrossRef] [PubMed]

212. Bravo, J.; Díaz, P.; Corvalán, A.H.; Quest, A.F.G. A Novel Role for Helicobacter pylori Gamma-Glutamyltranspeptidase in Regulating Autophagy and Bacterial Internalization in Human Gastric Cells. Cancers 2019, 11, 801. [CrossRef] [PubMed] 
213. Kim, K.M.; Lee, S.G.; Kim, J.M.; Kim, D.S.; Song, J.Y.; Kang, H.L.; Lee, W.K.; Cho, M.J.; Rhee, K.H.; Youn, H.S.; et al. Helicobacter pylori $\gamma$-glutamyltranspeptidase induces cell cycle arrest at the G1-S phase transition. J. Microbiol. 2010, 48, 372-377. [CrossRef] [PubMed]

214. Gong, M.; Ling, S.S.M.; Lui, S.Y.; Yeoh, K.G.; Ho, B. Helicobacter pylori $\gamma$-glutamyl transpeptidase is a pathogenic factor in the development of peptic ulcer disease. Gastroenterology 2010, 139, 564-573. [CrossRef]

215. Rimbara, E.; Mori, S.; Kim, H.; Shibayama, K. Role of $\gamma$-glutamyltranspeptidase in the pathogenesis of Helicobacter pylori infection. Microbiol. Immunol. 2013, 57, 665-673. [CrossRef]

216. Capitani, N.; Codolo, G.; Vallese, F.; Minervini, G.; Grassi, A.; Cianchi, F.; Troilo, A.; Fischer, W.; Zanotti, G.; Baldari, C.T.; et al. The lipoprotein HP1454 of Helicobacter pylori regulates T-cell response by shaping T-cell receptor signalling. Cell. Microbiol. 2019, 21, e13006. [CrossRef]

217. Waskito, L.A.; Miftahussurur, M.; Lusida, M.I.; Syam, A.F.; Suzuki, R.; Subsomwong, P.; Uchida, T.; Hamdan, M.; Nasronudin; Yamaoka, Y. Distribution and clinical associations of integrating conjugative elements and cag pathogenicity islands of Helicobacter pylori in Indonesia. Sci. Rep. 2018, 8, 6073. [CrossRef]

218. Morey, P.; Pfannkuch, L.; Pang, E.; Boccellato, F.; Sigal, M.; Imai-Matsushima, A.; Dyer, V.; Koch, M.; Mollenkopf, H.J.; Schlaermann, P.; et al. Helicobacter pylori depletes cholesterol in gastric glands to prevent interferon gamma signaling and escape the inflammatory response. Gastroenterology 2018, 154, 1391-1404. [CrossRef]

219. Jiang, F.; Wu, Z.; Zheng, Y.; Frana, T.S.; Sahin, O.; Zhang, Q.; Li, G. Genotypes and antimicrobial susceptibility profiles of hemolytic Escherichia coli from diarrheic piglets. Foodborne Pathog. Dis. 2019, 16, 94-103. [CrossRef]

220. Ellington, M.J.; Ekelund, O.; Aarestrup, F.M.; Canton, R.; Doumith, M.; Giske, C.; Grundman, H.; Hasman, H.; Holden, M.T.G.; Hopkins, K.L.; et al. The role of whole genome sequencing in antimicrobial susceptibility testing of bacteria: Report from the EUCAST Subcommittee. Clin. Microbiol. Infect. 2017, 23, 2-22. [CrossRef]

221. Pankhurst, L.J.; Del Ojo Elias, C.; Votintseva, A.A.; Walker, T.M.; Cole, K.; Davies, J.; Fermont, J.M.; Gascoyne-Binzi, D.M.; Kohl, T.A.; Kong, C.; et al. Rapid, comprehensive, and affordable mycobacterial diagnosis with whole-genome sequencing: A prospective study. Lancet Respir. Med. 2016, 4, 49-58. [CrossRef]

222. Witney, A.A.; Cosgrove, C.A.; Arnold, A.; Hinds, J.; Stoker, N.G.; Butcher, P.D. Clinical use of whole genome sequencing for Mycobacterium tuberculosis. BMC Med. 2016, 14, 46. [CrossRef] [PubMed]

223. Hurley, D.; Luque-Sastre, L.; Parker, C.T.; Huynh, S.; Eshwar, A.K.; Nguyen, S.V.; Andrews, N.; Moura, A.; Fox, E.M.; Jordan, K.; et al. Whole-genome sequencing-based characterization of 100 Listeria monocytogenes isolates collected from food processing environments over a four-year period. mSphere 2019, 4, e00252-19. [CrossRef] [PubMed]

224. Aly, M.A.; Domig, K.J.; Kneifel, W.; Reimhult, E. Whole Genome Sequencing-Based Comparison of Food Isolates of Cronobacter sakazakii. Front. Microbiol. 2019, 10, 1464. [CrossRef]

225. Walker, T.M.; Kohl, T.A.; Omar, S.V.; Hedge, J.; Elias, C.D.O.; Bradley, P.; Iqbal, Z.; Feuerriegel, S.; Niehaus, K.E.; Wilson, D.J.; et al. Whole-genome sequencing for prediction of Mycobacterium tuberculosis drug susceptibility and resistance: A retrospective cohort study. Lancet Infect. Dis. 2015, 15, 1193-1202. [CrossRef]

226. Metzker, M.L. Sequencing technologies-the next generation. Nat. Rev. Genet. 2010, 11, 31-46. [CrossRef]

227. Mardis, E.R. Next-generation DNA sequencing methods. Annu. Rev. Genom. Hum. Genet. 2008, 9, 387-402. [CrossRef]

228. Edwards, M.S.; McLaughlin, R.W.; Li, J.; Wan, X.-L.; Liu, Y.; Xie, H.-X.; Hao, Y.-J.; Zheng, J.-S. Putative virulence factors of Plesiomonas shigelloides. Antonie Van Leeuwenhoek 2019, 1-12. [CrossRef]

229. Lauener, F.N.; Imkamp, F.; Lehours, P.; Buissonnière, A.; Benejat, L.; Zbinden, R.; Keller, P.M.; Wagner, K. Genetic Determinants and Prediction of Antibiotic Resistance Phenotypes in Helicobacter pylori. J. Clin. Med. 2019, 8, 53. [CrossRef]

230. Tuan, V.P.; Narith, D.; Tshibangu-Kabamba, E.; Dung, H.D.Q.; Viet, P.T.; Sokomoth, S.; Binh, T.T.; Sokhem, S.; Tri, T.D.; Ngov, S.; et al. A Next-Generation Sequencing-Based Approach to Identify Genetic Determinants of Antibiotic Resistance in Cambodian Helicobacter pylori Clinical Isolates. J. Clin. Med. 2019, 8, 858. [CrossRef]

231. Chen, J.; Ye, L.; Jin, L.; Xu, X.; Xu, P.; Wang, X.; Li, H. Application of next-generation sequencing to characterize novel mutations in clarithromycin-susceptible Helicobacter pylori strains with A2143G of 23S rRNA gene. Ann. Clin. Microbiol. Antimicrob. 2018, 17, 10. [CrossRef] [PubMed]

232. Imkamp, F.; Lauener, F.N.; Pohl, D.; Lehours, P.; Vale, F.F.; Jehanne, Q.; Zbinden, R.; Keller, P.M.; Wagner, K. Rapid Characterization of Virulence Determinants in Helicobacter pylori Isolated from Non-Atrophic Gastritis Patients by Next-Generation Sequencing. J. Clin. Med. 2019, 8, 1030. [CrossRef] [PubMed] 
233. Gerrits, M.M.; van Vliet, A.H.; Kuipers, E.J.; Kusters, J.G. Helicobacter pylori and antimicrobial resistance: Molecular mechanisms and clinical implications. Lancet Infect. Dis. 2006, 6, 699-709. [CrossRef]

234. Ogawa, H.; Iwamoto, A.; Tanahashi, T.; Okada, R.; Yamamoto, K.; Nishiumi, S.; Yoshida, M.; Azuma, T. Genetic variants of Helicobacter pylori type IV secretion system components CagL and CagI and their association with clinical outcomes. Gut Pathog. 2017, 9, 21. [CrossRef]

235. Burton, P.R.; Clayton, D.G.; Cardon, L.R.; Craddock, N.; Deloukas, P.; Duncanson, A.; Kwiatkowski, D.P.; McCarthy, M.I.; Ouwehand, W.H.; Samani, N.J.; et al. Genome-wide association study of 14,000 cases of seven common diseases and 3,000 shared controls. Nature 2007, 447, 661-678.

236. Berthenet, E.; Yahara, K.; Thorell, K.; Pascoe, B.; Meric, G.; Mikhail, J.M.; Engstrand, L.; Enroth, H.; Burette, A.; Megraud, F.; et al. A GWAS on Helicobacter pylori strains points to genetic variants associated with gastric cancer risk. BMC Biol. 2018, 16, 84. [CrossRef]

237. Maldonado-Contreras, A.; Goldfarb, K.C.; Godoy-Vitorino, F.; Karaoz, U.; Contreras, M.; Blaser, M.J.; Brodie, E.L.; Dominguez-Bello, M.G. Structure of the human gastric bacterial community in relation to Helicobacter pylori status. ISME J. 2011, 5, 574-579. [CrossRef]

238. Jo, H.J.; Kim, J.; Kim, N.; Park, J.H.; Nam, R.H.; Seok, Y.J.; Kim, Y.R.; Kim, J.S.; Kim, J.M.; Kim, J.M.; et al. Analysis of gastric microbiota by pyrosequencing: Minor role of bacteria other than Helicobacter pylori in the gastric carcinogenesis. Helicobacter 2016, 21, 364-374. [CrossRef]

239. Schulz, C.; Schütte, K.; Koch, N.; Vilchez-Vargas, R.; Wos-Oxley, M.L.; Oxley, A.P.A.; Vital, M.; Malfertheiner, P.; Pieper, D.H. The active bacterial assemblages of the upper GI tract in individuals with and without Helicobacter infection. Gut 2018, 67, 216-225. [CrossRef]

240. Garrett, W.S. Cancer and the microbiota. Science 2015, 348, 80-86. [CrossRef]

241. Rooks, M.G.; Garrett, W.S. Gut microbiota, metabolites and host immunity. Nat. Rev. Immunol. 2016, 16, 341-352. [CrossRef] [PubMed]

242. Eun, C.S.; Kim, B.K.; Han, D.S.; Kim, S.Y.; Kim, K.M.; Choi, B.Y.; Song, K.S.; Kim, Y.S.; Kim, J.F. Differences in gastric mucosal microbiota profiling in patients with chronic gastritis, intestinal metaplasia, and gastric cancer using pyrosequencing methods. Helicobacter 2014, 19, 407-416. [CrossRef] [PubMed]

243. Coker, O.O.; Dai, Z.; Nie, Y.; Zhao, G.; Cao, L.; Nakatsu, G.; Wu, W.K.K.; Wong, S.H.; Chen, Z.; Sung, J.J.Y.; et al. Mucosal microbiome dysbiosis in gastric carcinogenesis. Gut 2018, 67, 1024-1032. [CrossRef] [PubMed]

244. Ferreira, R.M.; Pereira-Marques, J.; Pinto-Ribeiro, I.; Costa, J.L.; Carneiro, F.; Machado, J.C.; Figueiredo, C. Gastric microbial community profiling reveals a dysbiotic cancer-associated microbiota. Gut 2018, 67, 226-236. [CrossRef]

245. Mowat, C.; Williams, C.; Gillen, D.; Hossack, M.; Gilmour, D.; Carswell, A.; Wirz, A.; Preston T, T.; McColl, K.E. Omeprazole, Helicobacter pylori status, and alterations in the intragastric milieu facilitating bacterial N-nitrosation. Gastroenterology 2000, 119, 339-347. [CrossRef]

246. Williams, C.; McColl, K.E.L. Review article: Proton pump inhibitors and bacterial overgrowth. Aliment. Pharmacol. Ther. 2005, 23, 3-10. [CrossRef]

247. Wang, L.; Zhou, J.; Xin, Y.; Geng, C.; Tian, Z.; Yu, X.; Dong, Q. Bacterial overgrowth and diversification of microbiota in gastric cancer. Eur. J. Gastroenterol. Hepatol. 2016, 28, 261-266. [CrossRef]

248. Yang, I.; Woltemate, S.; Piazuelo, M.B.; Bravo, L.E.; Yepez, M.C.; Romero-Gallo, J.; Delgado, A.G.; Wilson, K.T.; Peek, R.M.; Correa, P.; et al. Different gastric microbiota compositions in two human populations with high and low gastric cancer risk in Colombia. Sci. Rep. 2016, 6, 18594. [CrossRef]

249. Gao, J.-J.; Zhang, Y.; Gerhard, M.; Mejias-Luque, R.; Zhang, L.; Vieth, M.; Ma, J.-L.; Bajbouj, M.; Suchanek, S.; Liu, W.-D.; et al. Association between gut microbiota and Helicobacter pylori-related gastric lesions in a high-risk population of gastric cancer. Front. Cell. Infect. Microbiol. 2018, 8, 202. [CrossRef]

(C) 2019 by the authors. Licensee MDPI, Basel, Switzerland. This article is an open access article distributed under the terms and conditions of the Creative Commons Attribution (CC BY) license (http://creativecommons.org/licenses/by/4.0/). 